\title{
Initiation and Regulation of CNS Autoimmunity: Balancing Immune Surveillance and Inflammation in the CNS
}

\author{
Melissa G. Harris ${ }^{1,2}$, Zsuzsanna Fabry ${ }^{1}$ \\ ${ }^{1}$ Department of Pathology and Laboratory Medicine, School of Medicine and Public Health, University of Wisconsin, Madison, USA; \\ ${ }^{2}$ Neuroscience Training Program, School of Medicine and Public Health, University of Wisconsin, Madison, USA. \\ Email: zfabry@facstaff.wisc.edu
}

Received June $7^{\text {th }}, 2012$; revised July $4^{\text {th }}, 2012$; accepted July $15^{\text {th }}, 2012$

\begin{abstract}
While the central nervous system (CNS) was once thought to be immune privileged, more recent data support that certain areas of the healthy CNS are routinely patrolled by immune cells. Further, antigen drainage is another means by which the adaptive arm of the immune system can gain information about the health of the CNS. Altogether these ensure that the CNS is not beyond the scope of immune protection against viruses and tumors. However, immune surveillance in the CNS has to be tightly regulated, as CNS autoimmune disease and inflammation may arise from increased immune cell infiltration. In this review we discuss the concept and implications of CNS immune surveillance and introduce the CNS antigen-presenting cells (APCs) that potentially regulate neuroinflammation and autoimmunity. We also discuss novel animal models in which CNS disease initiation and the role of APCs in disease regulation can be tested.
\end{abstract}

Keywords: CNS; Immune Surveillance, Autoimmunity; APCs; DCs; Oligodendrocyte Death; DAMPs; Initiation; Regulation

\section{Introduction}

The immune system has evolved to help the body fight foreign pathogens and harmful self-intruders, such as tumors. Immunity requires continual surveillance of the body by immune cells, primarily tissue-resident macrophages and dendritic cells (DCs), which initiate inflammatory responses that result in the recruitment of $\mathrm{T}$ cells and other leukocytes to the site of infection or damage. This process is highly restricted in the healthy central nervous system (CNS) due to several regulatory factors that preclude the infiltration of activated $\mathrm{T}$ cells from the blood into the CNS parenchyma, thus contributing to the immune privileged status of the CNS. In spite of this regulation, it has been shown that limited surveillance by $\mathrm{T}$ cells still promotes the health of this tissue. However, increased immunological surveillance and immune cell infiltration into the CNS may lead to inflammation and autoimmune disease [1,2]. One idea is that immune cells, particularly DCs, which accumulate in the CNS under inflammatory conditions may pick up and deliver myelin antigens to lymph nodes for the priming of adaptive immune responses. This process could lead to the initiation or exacerbation of CNS autoimmune disease. Thus, an understanding of how adaptive immunity is generated against CNS self-antigens and how it is regulated is nec- essary for treating diseases such as multiple sclerosis (MS). In this review we will focus on T cell-mediated adaptive immunity and will discuss conceptual changes in our understanding of CNS surveillance and the role of CNS antigen-presenting cells (APCs) in regulating adaptive immunity in the CNS. We will further discuss current models of CNS autoimmune disease initiation, and consider the potential contribution of damage-associated molecules to the exacerbation of CNS autoimmunity.

\section{CNS Immunity: Balancing Surveillance and Autoimmunity}

The CNS has historically been considered immune privileged. It was originally thought that antigens within the CNS parenchyma went unnoticed by circulating immune cells, mainly because the blood-brain barrier (BBB) kept them out (reviewed in [3]). This was thought to explain how foreign tissue grafts could survive in the CNS for long periods of time. It is now generally accepted that immune privilege is only afforded to the parenchyma, and not to the cerebrospinal fluid (CSF)-exposed parts of the CNS (i.e., leptomeninges, choroid plexus, circumventricular organs, and ventricles) [3]. The developed BBB (referred to as the neurovascular unit, or NVU) consists of not only vascular endothelial cells, but also 
the basement membrane of these cells and that of the astrocytic endfeet (i.e., the glia limitans), which delineate the CSF-filled perivascular space (PVS) that drains into the leptomeningeal subarachnoid space (SAS; Figure 1) (reviewed in [4]). Additionally, pericytes of the PVS, as well as neurons and extracellular matrix, are all part of the NVU (reviewed in [5]). Important to our discussion, the SAS is an active immunological niche that is crucial in the development and maintenance of CNS autoimmune disease.

Under homeostatic conditions $\mathrm{T}$ lymphocytes are restricted in their capacity to cross endothelial cells of the quiescent parenchymal BBB. However, activated T cells may cross into the SAS by binding adhesion molecules (namely, P-selectin via PSGL-1, but also ICAM-1) and cytokines (e.g., CCL20 via CCR6) constitutively expressed by endothelial cells of the meningeal $\mathrm{BBB}$ or epithelial cells of the choroid plexus, which form the blood-cerebrospinal fluid barrier (BCSFB; [6]; reviewed in $[4,7])$. Thus, activated $\mathrm{T}$ cells present in normal CSF and stroma of the choroid plexus and meninges are thought to carry out routine immune surveillance in the SAS $[6,8]$, which is rich in CNS antigens that drain into the CSF from interstitial fluid. This process is vital to the health of the CNS, as clinical reports have described pa- tients developing opportunistic viral infections in the CNS and subsequent progressive multifocal leukoencephalopathy when $\mathrm{T}$ cell transmigration is inhibited [9-11]. Of further clinical relevance, the SAS is believed to be the initial site of CCR6-mediated entry by pathogenic Th17 cells [12], which regulate the initiation of experimental autoimmune encephalomyelitis (EAE), the animal model of MS [13]. Interestingly, Th17 cells also mediate the formation of ectopic lymphoid follicles (eLFs) [14], which have been observed in the meninges of both mice with EAE [14,15] and patients with secondary (chronic) progressive MS [16,17]. These structures (discussed later) are thought to be important for maintaining chronic inflammation and may be key determinants for relapse and progression in the case of CNS autoimmune disease [17].

While it now seems clear that the CNS is immunologically monitored by activated $\mathrm{T}$ cells, which can be beneficial, the question remains: how do they become activated in the first place? With the exception of the CNS, every tissue in the body is connected to a complex network of lymphatic vessels. One of the key functions of this lymphatic system is to allow for drainage/homing of both soluble antigen and antigen-bearing cells (especially DCs) to peripheral lymphoid tissues to engage the

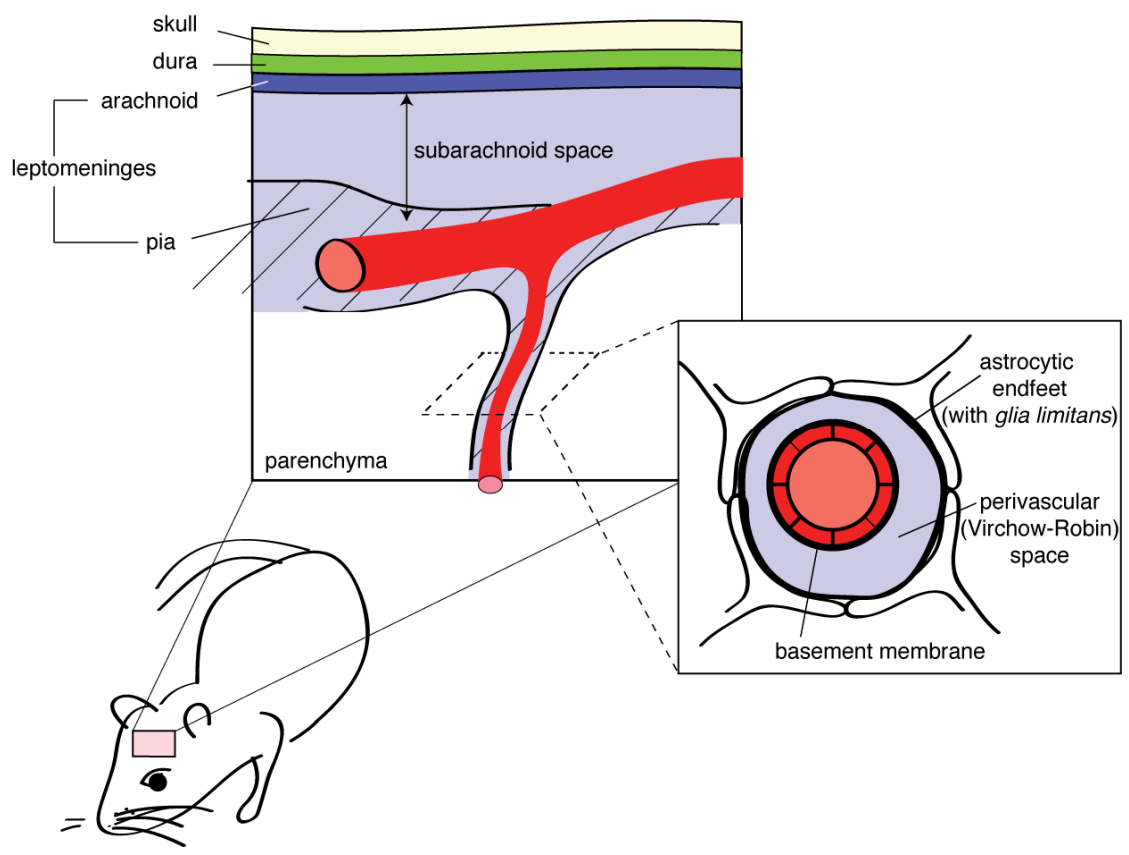

Figure 1. Anatomical locations supporting immune cell surveillance and entry into the CNS. Routine immune surveillance of the CNS is thought to occur by activated memory $T$ cells in the subarachnoid space (SAS) of the leptomeninges, which is comprised of the arachnoid mater and the pia mater (left picture). These $T$ cells may enter into the CSF-filled SAS either from postcapillary venules of the leptomeninges or across the epithelial cells of the choroid plexus, which form the blood-cerebrospinal fluid barrier (not shown). Together with neurons, the neurovascular unit (right picture) is comprised of the endothelial cells of the blood-brain barrier (BBB) and their underlying basement membrane, the perivascular space (PVS), and the basement membrane of the astrocytic endfeet forming the glia limitans. In the presence of neural inflammation, activated $T$ cells may cross the endothelial cells of the BBB into the PVS, presumably where they are re-primed by cognate antigen-bearing APCs that allow them to enter the CNS parenchyma. 
adaptive immune system. However, without draining lymphatics, how do antigens that are sequestered behind the $\mathrm{BBB}$ generate peripheral $\mathrm{T}$ cell responses? In the context of infection, it was proposed that bacterial or viral pathogens are allowed to persist in the CNS parenchyma without eliciting adaptive immune responses, which can only be generated following peripheral subcutaneous challenge with certain viruses [18-21]. In contrast, it is not known how normal, non-pathogenic CNS self-antigens (such as those from myelin) might drain and become the targets of autoimmune attack, despite the apparent immune privilege afforded to CNS pathogens. One possible explanation is that autoreactive $\mathrm{T}$ cell responses might develop following delayed-type hypersensitivity response to CNS infection, due to generation of new antigens created by bystander myelin damage [19]. However, in the absence of infection, it is hard to understand how this might occur.

The traditional method used to study soluble antigen drainage from the CNS has been intracerebral antigen injection. Using this technique, it was established that, despite the CNS not having conventional lymphatics, protein antigens injected intracerebrally into different parenchymal regions (i.e., caudate nucleus, internal capsule, and midbrain) and into CSF could be largely recovered in the cervical lymph nodes (CLNs) [22,23]. As reviewed by Cserr and Knopf [22], antigens may drain from the CNS into the blood by exiting the SAS through the arachnoid villi, which protrude into the dural sinus. The second exit is along the cranial nerves, in particular, along the olfactory pathway and nasal lymphatics to the CLNs [22]. To support the functional significance of this drainage process, it was shown that protein antigens that drain to the periphery are capable of eliciting adaptive immune responses [24,25], and may even be more immunogenic (as reflected in higher antibody titers) than the same antigens introduced peripherally [24]. We have also shown that both soluble and cell-bound intracerebrally injected antigens drain to the CLNs, and this is followed by the preferential recruitment of primed responder T cells to the CNS [26-29]. This accumulation of effector $\mathrm{T}$ cells in the CNS may be important because it has the potential to initiate and/or exacerbate autoimmune disease.

The technique of intracerebral antigen injection is a relatively easy and straightforward procedure in which antigen can be stereotaxically injected into desired locations of the brain. It is also fairly quantitative, giving the investigator control over the concentration of antigen or number of antigen-pulsed cells introduced. We previously reported a titration effect, in which the number of antigen-pulsed dendritic cells (DCs) injected into the brain positively correlated with their accumulation in the CLNs, as well as with the numbers of activated antigen- specific T cells recruited to the brain [26]. However, it is difficult to control for blood-brain barrier disruption, as minor tissue trauma from the needle injection may lead to inadvertent but minor immune cell activation and recruitment to the CNS [22]. Another limitation of this technique is that it disconnects antigen release and cellular signals associated with cell death (i.e., damage-associated molecular patterns, or DAMPs), thereby precludeing study of the potentially immunogenic role of DAMPs in priming CNS antigen-specific adaptive immune responses.

To overcome the above listed limitations, newer models have more recently been created to test the critical questions of how CNS cell-specific neoantigens are recognized by the peripheral immune system, and how this recognition leads to CNS pathology. Notably, neural cell-specific neoantigen models have been created in which expression of immunogenic antigens is restricted to neurons [30,31], astrocytes [32], oligodendrocytes (ODCs) [33,34], and both ODCs and Schwann cells [35], and is achieved either by using Cre driver transgenic mouse lines or by having the neoantigens under direct neural cell-specific promoter control. These models are being used to understand mechanisms of immune tolerance and reactivity to CNS antigens, the findings of which are summarized in Table 1. We created mice with myelinating glial cell-specific expression of major histocompatibility complex (MHC) class I- and MHC class II-restricted ovalbumin neoepitopes in order to study the mechanism of myelinating cell-specific antigen recognition by immune cells and requirements for antigen-specific CD4+ or CD8+ $\mathrm{T}$ cell infiltration in the CNS under normal and inflammatory conditions. Our findings suggest that myelinating cell-specific neoantigen expression itself is not sufficient to induce neoantigen-specific $\mathrm{T}$ cell accumulation into the CNS. Other signals induced by neuroinflammation are required for the accumulation of neoantigen-specific CD8+ T cells in the CNS. We also found that ovalbumin neoantigen-specific CD8+ T cells exacerbate myelin oligodendrocyte glycoprotein (MOG)induced inflammation in EAE (manuscript in preparation). This supports the overall hypothesis that increased $\mathrm{T}$ cell surveillance could contribute to the initiation and maintenance of CNS autoimmunity.

\section{Antigen-Presenting Cells in the CNS: Locations, Function, and Subtypes}

As discussed above, activated $\mathrm{T}$ cells routinely survey the SAS of the healthy CNS, yet how and where CNS-infiltrating $\mathrm{T}$ cells are initially primed in humans and the conditions under which this leads to autoimmunity are unknown. Once primed, however, these T cells must then re-encounter their antigen in the appropriate 
Table 1. Neural cell-specific neoantigen models.

\begin{tabular}{|c|c|c|c|c|c|c|}
\hline Cell type & $\begin{array}{l}\text { Promoter or } \\
\text { Cre driver line }\end{array}$ & $\begin{array}{l}\text { Neoantigen or } \\
\text { Neoantigen/Lox } \\
\text { line }\end{array}$ & $\begin{array}{c}\text { Neoantigen } \\
\text { localization } \\
\text { (and/or site of } \\
\text { normal protein } \\
\text { expression } \\
\text { [Ref]) }\end{array}$ & Major Finding & Additional comments & $\begin{array}{l}\text { Reference } \\
\text { (s) }\end{array}$ \\
\hline ODCs & MOGi-Cre & $\begin{array}{c}\text { Influenza } \\
\text { hemagglutinin } \\
\text { (Rosa } 26^{\text {tm(HA)1Lib1 }} \\
\text { mice) }\end{array}$ & $\begin{array}{c}\text { unspecified } \\
\text { (myelin sheath } \\
[34])\end{array}$ & $\begin{array}{l}\text { ODC-targeted attack by } \\
\text { pre-activated } \\
\text { neoantigen-specific CTLs } \\
\text { and neurological disease }\end{array}$ & $\begin{array}{c}\text { Ignorance of neoantigen by } \\
\text { neoantigen-specific CD8+ T } \\
\text { cells in Lox/Cre x CL4-TCR } \\
\text { mice }\end{array}$ & {$[34,37]$} \\
\hline ODCs & MBP & $\begin{array}{l}\text { floxed ovalbumin } \\
\text { (ODC-OVA mice) }\end{array}$ & $\begin{array}{c}\text { cytosolic } \\
\text { (cytoplasmic } \\
\text { side of } \\
\text { membrane }[38] \text { ) }\end{array}$ & $\begin{array}{l}\text { Neoantigen-specific CD8+ T } \\
\text { cells induce ODC death and } \\
\text { neurological disease in } \\
\text { ODC-OVA x OT-I mice }\end{array}$ & $\begin{array}{c}\text { Ignorance of neoantigen by } \\
\text { neoantigen-specific } \\
\text { CD4+ T cells in ODC-OVA x } \\
\text { OT-II mice }\end{array}$ & {$[33,39]$} \\
\hline $\begin{array}{l}\text { ODCs/Schwann } \\
\text { cells }\end{array}$ & $\begin{array}{l}\text { PLP-CreERT2/ } \\
\text { (inducible) }\end{array}$ & $\begin{array}{l}\text { LCMV- and } \\
\beta \text {-gal-derived CD8+ } \\
\text { T cell neoepitopes } \\
\text { (ST33.396 mice) }\end{array}$ & $\begin{array}{l}\text { Unspecified } \\
\text { (myelin sheath } \\
{[40] \text { ) }}\end{array}$ & $\begin{array}{l}\text { Endogenous CD } 8+\mathrm{T} \text { cell } \\
\text { tolerance to neoantigens } \\
\text { induced by DCs }\end{array}$ & - & {$[35,41]$} \\
\hline $\begin{array}{l}\text { astrocytes and } \\
\text { enteric glial cells }\end{array}$ & GFAP & $\begin{array}{c}\text { influenza } \\
\text { hemagglutinin }\end{array}$ & cytoplasm [42] & $\begin{array}{c}\text { Neoantigen-specific CD4+ T } \\
\text { cell ignorance in GFAP-HA } \\
\text { x HNT-TCR mice }\end{array}$ & - & {$[32]$} \\
\hline neurons & NSE & ovalbumin & $\begin{array}{c}\text { cell } \\
\text { surface/ } \\
\text { membrane [43] }\end{array}$ & $\begin{array}{l}\text { intracerebral infection with } \\
\text { Listeria monocyto- } \\
\text { genes-ovalbumin induces } \\
\text { neurological disease, medi- } \\
\text { ated by } \\
\text { SIINFEKL-specific CD8+ T } \\
\text { cells }\end{array}$ & $\begin{array}{l}\text { No endogenous } \mathrm{OVA}_{323-339} \\
\text { CD4+ response }\end{array}$ & {$[30]$} \\
\hline neurons & CamK-iCre & $\begin{array}{c}\text { influenza } \\
\text { hemagglutinin } \\
\text { (Rosa26 } \\
\text { mice) }\end{array}$ & $\begin{array}{l}\text { unspecified } \\
\text { (cytosolic or } \\
\text { anchored to } \\
\text { cytoskeleton, } \\
\text { depending on } \\
\text { isoform [44]) }\end{array}$ & $\begin{array}{l}\text { transient encephalomyelitis } \\
\text { but development of chronic } \\
\text { diabetes } \\
\text { insipidus due to } \\
\text { destruction of } \\
\text { hypothalamic neurons by } \\
\text { neoantigen-specific CTLs }\end{array}$ & - & {$[31,45]$} \\
\hline
\end{tabular}

ODCs = oligodendrocytes; $\mathrm{MOG}=$ myelin oligodendrocyte glycoprotein; $\mathrm{MBP}=$ myelin basic protein; PLP = proteolipid protein; GFAP = glial fibrillary acidic protein; NSE = neuron-specific enolase promoter; CamK = calcium/calmodulin-dependent kinase; CTL = cytotoxic T lymphocyte; TCR = T cell receptor; HA $=$ hemagglutinin.

MHC context by a functional (and as yet uncharacterized) APC before entering the CNS parenchyma and initiating disease $[7,46]$. Naïve T cells that might indiscriminately enter the CNS once inflammation is established also require antigen in order to become activated in situ in the CNS [47]. It was proposed that this process is limited in the healthy CNS, however, as there is no clear evidence that DCs, the only cells capable of activating naive $\mathrm{T}$ cells, are present in the healthy CNS parenchyma in detectable numbers [3]. However, cells that carry common features of DCs, such as OX62 [48,49], MHC class II, and the integrin alpha $X$ molecule CD11c [8,50], have been shown in the healthy rodent meninges and choroid plexus. These meningeal/choroid plexus APCs might represent a unique subpopulation of DCs that can contribute to the development and regulation of CNS autoimmunity. Additionally, DCs do accumulate in the inflamed CNS [48,51-53], indicating that these cells are important for the maintenance of chronic inflammation in these tissues.

In this section we focus on microglia, astrocytes, and DCs as in situ CNS APC candidates, potentially capable of regulating the initiation of neuroinflammation. Things to consider in evaluation of their APC candidacy are 1) how efficiently they activate $\mathrm{T}$ cells through upregulation of co-stimulatory molecules (in particular, CD40, CD80 
(B7-1), CD86 (B7-2), and ICAM-1) and also MHC class I and II; and 2) their ability to process and present CNS self-antigen. As CD8+ T cells are the dominant subset of inflammatory infiltrates observed in MS lesions [54], the ability of the candidate APCs to cross-present exogenously-derived antigen to CD8+ $\mathrm{T}$ cells will also be given special consideration apart from activation of CD4+ T cells, which govern EAE pathology. Additionally, CNS-associated macrophages (found in the choroid plexus, meninges, and perivascular space), as well as endothelial cells and pericytes, may also be involved in antigen presentation and disease pathology [55-60], but they will not be discussed here.

\subsection{Microglia: Providers of Neuronal Support and Parenchymal Surveillance}

The "oldest" APCs that were proposed to contribute to CNS immunity were the microglia and were first described by Pio del Rio-Hortega (reviewed in [61]). Microglia are abundant everywhere in the CNS [61] and are considered CNS-resident macrophages that arise from a primitive myeloid progenitor population in the extraembryonic yolk sac that enters the embryonic brain as blood vessels begin to develop (E9.5) [62]. The differenttiation of the shared common myeloid progenitor into the granulocyte-monocyte progenitor (which further differentiates into monocytes, DCs, and macrophages) takes place during another developmental wave in the fetal liver ("definitive hematopoiesis"), and eventually occurs in the bone marrow (reviewed in [63]). Additionally, microglia can renew in situ without contribution from circulating hematopoietic cells [62]. While microglia are known phagocytes of cellular material in health and disease [64], one of their primary functions in the healthy CNS is to maintain neuronal synapses, which is in part reflected by their ramified (non-macrophage-like) morphology [65]. Likewise, they are under tight regulatory control by active neurons (reviewed in [66,67]). However, and of relevance in terms of innate immunity, microglia also provide routine and active surveillance of the nervous tissue and are thus immediate responders to danger. Their production of chemokines and proinflammatory cytokines allows for the recruitment and entry of immune cells from the periphery [66].

In terms of their antigen-presenting capacity, resting microglia (i.e., $\mathrm{CD} 11 \mathrm{~b}^{+} \mathrm{CD} 45^{\text {low }}$ ) express very low levels of MHC class I and II and the costimulatory molecules CD40, CD80, CD86, and ICAM-1, making them less efficient at priming naïve T cells compared to DCs [68]. This was demonstrated in earlier in vitro experiments, in which resting microglia isolated from neonatal mouse brains required signaling through $\mathrm{B} 7 / \mathrm{CD} 28$ (endowed by the addition of IFN- $\gamma$ and granulocyte-macrophage colony-stiumulating factor, GM-CSF) and CD40/CD40L in order to serve as more efficient "professional" APCs [69]. In contrast, peripheral DCs were demonstrated to be much more efficient APCs than activated microglia in their ability to prime naïve $\mathrm{T}$ cells; however, microglia were just as effective as DCs in their ability to prime helper T (Th) cell lines [70]. In vivo, microglia have a relatively limited capacity to "pick up" and present antigens to naïve $\mathrm{T}$ cells infiltrating the inflamed CNS. Results from S. Miller's group show that microglia isolated from the CNS of mice with relapsing-EAE (R-EAE) remain relatively poor stimulators of naïve proteolipid protein PLP $\mathrm{P}_{139-151}$-specific CD4+ T cells ex vivo, and only become strong stimulators upon addition of exogenous antigen at a very high APC:T cell ratio (1:1) [71]. However, they could stimulate CD4+ T cell lines much more efficiently. Recently, microglia isolated from the brain of naïve adult wild type mice have also been shown to be capable of TAP-dependent cross-presentation of soluble antigen in vitro and also intracerebrally injected antigen ex vivo to naïve $\mathrm{CD} 8+\mathrm{T}$ cells and $\mathrm{T}$ cell lines [72]. This ability was enhanced in microglia when stimulated with GM-CSF or CpG oligodeoxynucleotide. However, these results were obtained using very high concentrations of antigen $(100-200 \mu \mathrm{M}$ in vitro $)$ at a very high APC:T cell ratio (2:1), and likely do not reflect how much antigen is normally taken up in vivo, which (as the data in [71] suggests) is probably very little. Additionally, in all of these studies it is difficult to compare the efficiency with which microglia can stimulate effector $\mathrm{T}$ cell lineages that develop in vivo with their ability to stimulate $\mathrm{T}$ cell lines in vitro, since $\mathrm{T}$ cell lines require very minimal stimulation in order to become activated.

While activated microglia (i.e., CD $11 \mathrm{~b}^{+} \mathrm{CD} 45^{\text {high }}$ ) characterize most neuroinflammatory diseases, their actual contribution to CNS injury or protection is controversial. In response to neuroinflammation, activated microglia can upregulate all of the co-stimulatory molecules needed for facilitating adaptive immune responses in the CNS, which have been found in human MS tissue ([73], and the references therein). Prior to the manifestation of EAE clinical symptoms, microglia activation and proliferation have been noted [74], and temporally coincide with the entry of IL-17- and IFN- $\gamma$-producing T cells into the brain [75]. At this time microglia also start to upregulate MHC class II, CD40, CD80, and CD86 molecules, suggesting that their primary role in this early phase is to re-activate entering $\mathrm{T}$ cells or to prime naïve $\mathrm{T}$ cells indiscriminately entering the inflamed CNS [75]. Indeed, EAE was greatly attenuated in ganciclovir (GCV)treated bone marrow chimeric CD11b-HSVTK mice (i.e., having $C D 11 b$ promoter-driven, GCV-responsive herpes simplex virus thymidine kinase), which have paralyzed microglia but otherwise functional CD11b-expressing monocytic/macrophage cells [76]. Additionally, there were 
fewer lymphocytes in the CNS of these mice. These studies illustrate that microglia contribute to the development of CNS autoimmune disease. However, microglia have also been shown to have suppressive functions, as in vitro activated microglia presenting the immunogenic myelin basic protein (MBP) Ac1-11 peptide have been shown to induce T cell anergy and death $[69,77]$. This tolerogenic outcome (as opposed to T cell activation) in vivo would depend on both $\mathrm{T}$ cell avidity for self-antigen (i.e., the number of peptide/MHC complexes, as well as the affinity of the $\mathrm{T}$ cell receptor for the peptide/MHC complex), which may increase under neuroinflammatory conditions [7], and also the local cytokine milieu, which influences the activation level of APCs in the CNS. Undoubtedly, the function of microglia needs to be further studied, as these cells might be important in both the induction and regulation of CNS autoimmunity.

Cytokines have been shown to exert a strong influence on the phenotype acquired by peripheral monocyte-derived macrophages, which have been classified as either classically activated (pro-inflammatory M1; polarized by lipopolysaccharide and IFN- $\gamma$ ) or alternatively activated (anti-inflammatory M2; polarized by IL-4, IL-10, IL-13, and TGF- $\beta$ ) (reviewed in [78], and the references therein). These phenotypes may apply to microglia as well; however, this has not been demonstrated in vivo. It was shown that microglia with a constitutive IL-4-driven alternatively activated (M2-like) phenotype are actively involved with suppression of neuroinflammation, as EAE is very severe in bone marrow chimeric mice that lack IL-4 cytokine in the CNS compared to control chimeric mice [79]. Interestingly, M2 macrophages can be re-polarized to an M1 phenotype in vivo at the site of injury in a spinal cord injury model [80], suggesting that factors within the lesion itself contributed to macrophage phenotype polarization with corresponding pro- or anti-inflammatory function. Additionally, regional differences in local microenvironmental factors may influence macrophage phenotype within the same lesion (or between lesions). This is supported by immunostaining of CNS tissue from MS patients, which showed higher numbers of macrophage/microglia with a more M2-like phenotype (characterized by expression of CD163) within acute active lesions and on the edge of chronic active lesions, i.e., sites of active inflammation, than in the center of chronic active lesions [81]. These cells also expressed MHC class II and stained positive for myelin, indicating that they had the capacity to present myelin antigen to $\mathrm{T}$ cells and perhaps could induce a regulatory $\mathrm{T}$ cell response. Collectively, these results suggest that the type of adaptive response that is promoted by microglia is, in part, determined by local microenvironmental cues.

New data cast doubt on the role of microglia in chronic disease progression. Using an elegant parabiosis technique combined with irradiation, in which blood circulation from one mouse is allowed to naturally enter the blood circulation of the irradiated partner, Ajami et al. recently demonstrated that while activated microglia are present at EAE disease onset, it is the monocytes that are recruited to the CNS from the blood after this initial phase that are required for disease progression [82]. Instead, at this late stage, microglia may be more involved with tissue repair or inhibiting further $\mathrm{T}$ cell activation. A recent study examined the CNS expression profiles of various co-stimulatory signals required for $\mathrm{T}$ cell activation during the different phases of EAE [83]. The authors found that B7.2 expression on non-ramified cells during the inductive and peak phases of EAE was largely restricted to areas around blood vessels, whereas ramified $\mathrm{B} 7.2+$ microglia were found in increasing numbers during the recovery phase in the perivascular areas and somewhat in the parenchyma. Additionally, they found an accumulation of CTLA-4+ cells near the blood vessels in the recovery phase of EAE. These results suggest that $\mathrm{T}$ cells entering the parenchyma during EAE may be induced to undergo anergy, as there is very little co-stimulatory B7.2 expression in this area at this time. At later phases, microglia may induce inhibition in effector cells entering from the blood vessels through CTLA-4 signaling, which has been shown to negatively regulate $T$ cells (reviewed in [84]). Therefore, microglia might play a dual role in inhibiting lymphocytes and promoting tolerance during CNS autoimmune disease.

\subsection{Astrocytes: Not Antigen-Presenting Cells in Vivo but Contributors to BBB Integrity}

Astrocytes are one of the two types of CNS-resident macroglia (the other being the oligodendrocytes) and arise from the neuroectoderm during embryonic development. They have many roles - chief among them is facilitating neuronal synaptic transmission by removing and recycling excess neurotransmitters from the extracellular space [85]. Their communication with active neurons and close connection with blood vessels penetrating the CNS parenchyma also allows them to regulate blood flow by signaling to smooth muscle cells within the vessel walls [86]. Unlike microglia, astrocytes are not considered immune cells. However, astrocytic endfeet form the glia limitans, which is an essential component of the neurovascular unit (described above) and another barrier to $\mathrm{T}$ cell infiltration. The question of whether astrocytes can present antigens to $T$ cells will next be considered.

It is generally accepted that non-stimulated astrocytes are very poor APCs and, like microglia, express very low or no constitutive levels of costimulatory and MHC molecules. However, activated astrocytes express in- 
creased levels of MHC class II and B7-1 molecules in vitro, but not B7-2 and CD40, which remain at baseline levels [87]. This suggests that they would be weak inducers of $\mathrm{T}$ cell activation at least in vitro, if not also in vivo. Indeed, compared to activated astrocytes, naïve astrocytes from primary cultures have almost no ability to induce proliferation or IFN- $\gamma$ production in $\mathrm{PLP}_{139-151^{-}}$ specific CD4+ effector T cell lines [87]. Activated astrocytes are only slightly better in their capacity to induce proliferation of effector $\mathrm{CD} 4+\mathrm{T}$ cells from $\mathrm{T}$ cell lines than are naïve astrocytes, but cannot induce proliferation or effector cytokine production (e.g., IL-2, IL-4, IFN- $\gamma$ ) in naïve CD4+ T cells at all [70]. However, activated astrocytes have been shown to induce low IFN- $\gamma$ production by effector $\mathrm{T}$ cells $[70,87]$, though they seem to be even better at inducing IL-4 and IL-10 cytokine production, and so they may have a role in forming a Th2-polarizing environment $[68,70]$.

While activated astrocytes have some capacity to process myelin protein and present encephalitogenic myelin antigens in vitro [88, 89], their pathogenic role in the CNS autoimmune disease process is dubious at best. Mice in which astrocytes constitutively express the transcription factor CIITA (required for MHC class II protein expression in astrocytes) have a similar EAE disease course to wild type mice, despite these astrocytes having upregulated message levels of CIITA (the transcription factor associated with MHC class II expression) and the components that are involved in the assembly of peptide/MHC class II complexes (invariant chain (Ii) and H-2M molecules) [90]. Finally, astrocytes have been shown to present soluble viral peptide antigen to naïve $\mathrm{CD} 8+\mathrm{T}$ cells in vitro [91]. While astrocytes engineered to express viral neoantigen may activate effector CD8+ T cells in vivo and initiate disease [92], true cross-presentation of viral or myelin antigens by astrocytes in vivo has never been tested. Given their poor ability to phagocytose myelin antigen compared to microglia [93], it seems unlikely that they have any significant contribution in the presentation of self-antigen to $\mathrm{T}$ cells recruited to the CNS during neuroinflammation.

Based on these studies, there is no major role for astrocytes in inducing adaptive immune responses in the CNS in vivo. However, undoubtedly, these cells play a critical role in supporting BBB and neuron functions (reviewed in [94]).

\subsection{Dendritic Cells: Major Players in CNS Immunity}

In the last few years, interest has focused on DCs in the initiation of CNS autoimmunity, as these cells have emerged as potential targets for modulating immune diseases of the nervous tissue. DCs are highly specialized, professional APCs that reside in tissues in an immature state, where they capture and process antigens. Antigen-bearing DCs mature en route to the peripheral lymphoid tissues, where they play a crucial role in $\mathrm{T}$ cell activation and differentiation, as well as tolerization. They are the most efficient of all the professional APCs at priming naïve $\mathrm{T}$ cells, given their ability to migrate and rapidly upregulate the necessary costimulatory and MHC molecules. While this knowledge comes from studying DCs in peripheral, non-CNS tissues, until recently little was known about their immunosurveillant role in the CNS. In one of the first studies to characterize the presence of DCs in various non-lymphoid tissues, it was suggested that their absence in the normal rat parenchyma contributed to CNS immune privilege [95]. Thus, cells within the CNS (e.g., microglia and astrocytes) were studied for their role in autoimmune disease pathogenesis. But then, almost three decades after their initial description by Steinman and Cohn [96], DCs were identified in the perivascular space, choroid plexus, and meninges in rodents $[48,49]$, where they localized in different aspects of these tissues (i.e., CSF-exposed) than macrophages [97]. Since then, both plasmacytoid and myeloid DC subsets have been found in CSF in humans [98].

The identification of this professional APC in CSF-exposed parts of the CNS has radically reshaped our ideas about the immune-privileged nature of the CNS and the mechanism of CNS autoimmune disease initiation. Upon their discovery, it was proposed that DCs in these non-parenchymal CNS tissue areas might acquire antigens obtained from CSF, exit the CNS via the olfactory pathway and nasal lymphatics, and stimulate the appropriate T cells within the CLNs $[19,49]$. Experimental support for the crucial role of DCs in the CNS autoimmune disease process came in a landmark study, in which Greter et al. used mice that had DC-restricted expression of MHC class II to show that DCs within the meninges and CNS blood vessels, but not parenchymal MHC class II+ cells (i.e., microglia or astrocytes), were necessary and sufficient to induce EAE [99]. DCs have also been shown to regulate the process of epitope spreading in the CNS, in which naïve T cells are primed against antigens that are different than the one used to induce disease [71]. This process is thought to underlie the relapses that patients suffer in relapsing-remitting MS. In this study, DCs isolated from the inflamed CNS of

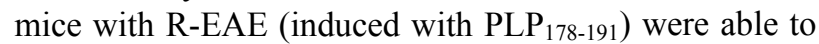
cross-present non-immunizing epitopes that they had picked up in vivo to prime naïve $\mathrm{PLP}_{139-151}$-specific $\mathrm{T}$ cells ex vivo [71]. Additionally, studies in our lab have demonstrated that DCs can promote T-T cell interactions, which facilitates their entry into the CNS [100]. Thus, the evidence is growing that DCs are critical regulators of 
adaptive immune responses in the CNS. Special consideration of the role of DCs in tolerance and immunity to CNS self-antigens will be given later in this review.

The discovery of DCs in the CSF-exposed parts of the healthy CNS suggested that these cells might be important in the regulation of adaptive immune responses within the CNS. The CNS was now viewed as being relatively, rather than absolutely, immune privileged. In terms of disease mechanisms, the potential for development of CNS autoimmunity arises should the DCs be presenting neural self-antigens, yet it would be simplistic to think that this would be the inevitable outcome. There exist many central and peripheral tolerance mechanisms and cellular regulators of immunity (for example, induction of $\mathrm{T}$ cell anergy; clonal deletion; induction of/regulation by regulatory $\mathrm{T}$ cells, myeloid-derived suppressor cells, and alternatively activated macrophages) that prevent self-reactive $\mathrm{T}$ cells from becoming activated [101-103]. The conditions in which antigens draining from the CNS induce and/or break peripheral tolerance are unknown but are essential to understanding how peripherally located CNS antigen-specific T cells become pathogenic and/or contribute to autoimmune disease.

A remaining unanswered question is whether CNS antigen-specific naïve $\mathrm{T}$ cells are primed by $\mathrm{DCs}$ in the CLNs, or whether they are primed by DCs in the SAS. McMahon and colleagues have shown that while initial priming of naïve $\mathrm{CD} 4+\mathrm{T}$ cells occurs in the periphery as a result of the R-EAE immunization protocol, those specific for non-immunizing epitope that have newly arrived in the CNS are primed locally by DCs [71]. However, Walter and Albert reported that cross-presentation of membrane-bound antigens on splenocytes lacking MHC class I first occurs in the CLNs before responder T cell recruitment to the CNS [104]. Collectively, these results suggest that antigen drainage to the CLNs is one of the first steps regulating activated $\mathrm{T}$ cell recruitment to the CNS and, thus, is a key component of CNS surveillance, but that local stimulation in the CNS may be crucial to disease progression. For example, DCs in the SAS may contribute both to priming of Th17 cells and to the formation of eLFs by producing CXCL13 [15,17], which binds to CXCR5 expressed on Th17 cells that may assume follicular helper $\mathrm{T}$ cell-like functions.

Finally, there has been some recent investigation into the origin of CNS DCs that are present under neuroinflammatory conditions, namely, whether they originate from a precursor in the CNS or enter from the blood. Microglia, for instance, can take on a DC-like phenotype when exposed to GM-CSF, or a more macrophage-like phenotype when exposed to M-CSF (macrophage colony-stimulating factor) [105]. Mice with CD11c promoter-driven expression of GFP [106] and EYFP [107] have been used to probe the presence and distribution of
DCs in the normal CNS parenchyma $[108,109]$, where the reporter cells seem to have definite DC morphology and functionality. Bulloch and colleagues identified stellate EYFP+ cells in areas of the normal brain lacking a BBB (e.g., circumventricular organs), which they proposed was perhaps indicative of the role of these cells in immunosurveillance and antigen presentation [108]. In the other model, the GFP + cells were also identified in several parenchymal areas, but their dendritic processes were found to directly connect with the glia limitans, which, again, may be related to their role in antigen presentation in the perivascular space [109]. Functionally, IFN- $\gamma$-activated EYFP+ cells were able to migrate and upregulate MHC class II in vivo, and were better at stimulating naïve $\mathrm{CD} 4+\mathrm{T}$ cells than EYFP- microglia $e x$ vivo, consistent with established DC properties [110]. However, it must be noted that CD11c expression is not restricted to classical myeloid DCs, and, thus, alone it may not reliably be used to determine lineage [111]. The data from the reporter studies show that parenchymal GFP+ and EYFP+ reporter cells colocalize with microglia/macrophage markers F4/80, and Iba-1 and myeloid marker $\mathrm{CD} 11 \mathrm{~b}$, suggesting that parenchymal $\mathrm{CD} 11 \mathrm{c}+$ cells may be a subset of resident microglia $[108,109]$. Using the CD11c-EYFP reporter mice, it has recently been shown that EYFP+ cells only in the meninges and choroid plexus (but not in the parenchyma) of the healthy CNS expand in response to FMS-like tyrosine kinase receptor 3 ligand (Flt3L), which is necessary for DC lineage commitment [50]. Additionally, these DCs resembled splenic DCs in terms of their mRNA profile of several cell surface/lineage markers and transcription factors, as well as in their ability to stimulate naïve $T$ cells, and were thus distinctly different from parenchymal microglia. These new findings support that pre-DCs in the meninges and choroid plexus enter from the blood and differentiate into mature DCs in situ. Against the idea that DCs found in the inflamed CNS are of microglia origin, bone marrow chimeric mice have previously been used to show that the majority (i.e., more than eighty percent) of DCs present in the CNS of mice with R-EAE are from the bone marrow [112].

In summary, DCs in the perivascular space and meninges are the choice cellular candidate responsible for priming naïve and restimulating CNS antigen-specific $\mathrm{T}$ cells. Once inside the parenchyma proper, activated $\mathrm{T}$ cells can then interact with CNS-resident astrocytes and microglia. Microglia may present antigen to infiltrating effector $\mathrm{T}$ cells and are perhaps more involved with negative regulation of disease.

\section{Initiation of CNS Autoimmunity: The Perfect Immunological "Storm"}

Many of our ideas about the pathogenic mechanisms 
underlying chronic neuroinflammatory diseases, such as MS, come from studying the EAE animal model. In this model, disease may be initiated by either immunizing the animal with a myelin antigen ("active" induction), or by adoptively transferring activated, encephalitogenic $\mathrm{T}$ cells ("passive" induction). Under both experimental conditions, activated $\mathrm{T}$ cells from the periphery infiltrate the healthy CNS and contribute to disease. Yet in humans with MS, it is difficult to determine what drives the entry of myelin antigen-specific $\mathrm{T}$ cells into the CNS. Because of the preponderance of these and macrophage cells in active demyelinating lesions and elevated levels of chemokines and proinflammatory Th1 cytokines in CSF, MS is widely accepted to be a $\mathrm{T}$ cell-mediated autoimmune disease [113-115]. Thus, the standard model is that myelin-reactive $\mathrm{T}$ cells initiate oligodendrocyte death and mediate further myelin destruction by soliciting the recruitment of macrophages. However, given the different histopathological patterns displayed in active MS lesions [116], the question arises whether MS is primarily an autoimmune disease, or whether adaptive immunity is secondary to a different underlying cause. This is tremendously important in terms of how the disease is treated and is a subject of intense debate.

Infection is one of several potential triggers of CNStargeted adaptive immune responses and has received much attention. An infectious pathogen might drive the cross-activation of CNS antigen-specific T cells due to similarities in epitope sequence homology or molecular conformation (this is called molecular mimicry). In addi- tion, pathogens display conserved molecules (i.e., pattern-associated molecular patterns, PAMPs), which can bind to pattern recognition receptors, such as Toll-like receptors, on APCs and induce their activation, thus facilitating efficient presentation of the pathogenic/self antigen. Mice infected with a neurotropic virus engineered to express a myelin-self-antigen develop paralytic demyelinating disease induced by cross-reactive CD4+ T cells [117]. In a similar study, CD8+ T cell-mediated attack of ovalbumin (OVA)-expressing neurons was initiated following intracerebral injection with OVA-secreting Listeria monocytogenes [30]. It is important to note that in this experiment, peripheral infection alone did not induce disease, suggesting that CNS inflammation and breakdown of the BBB are also required. While no specific virus has been causally linked to human MS, deep sequencing technology is now being used to detect new viruses from MS brain samples and will likely yield strong correlational data [118].

Another model of CNS autoimmune disease initiation has been proposed based on the histological observation that oligodendrocyte (ODC) apoptosis precedes immune cell infiltration in new lesions in several cases of relapsing-remitting MS [119]. The idea is that some unknown factor that causes ODC death also results in the direct or indirect activation of CNS APCs, leading to their migration to CLNs and the priming of naïve $\mathrm{T}$ cells, which then get recruited to the CNS (Figure 2) [120]. The power of modeling primary ODC death as an initiator of

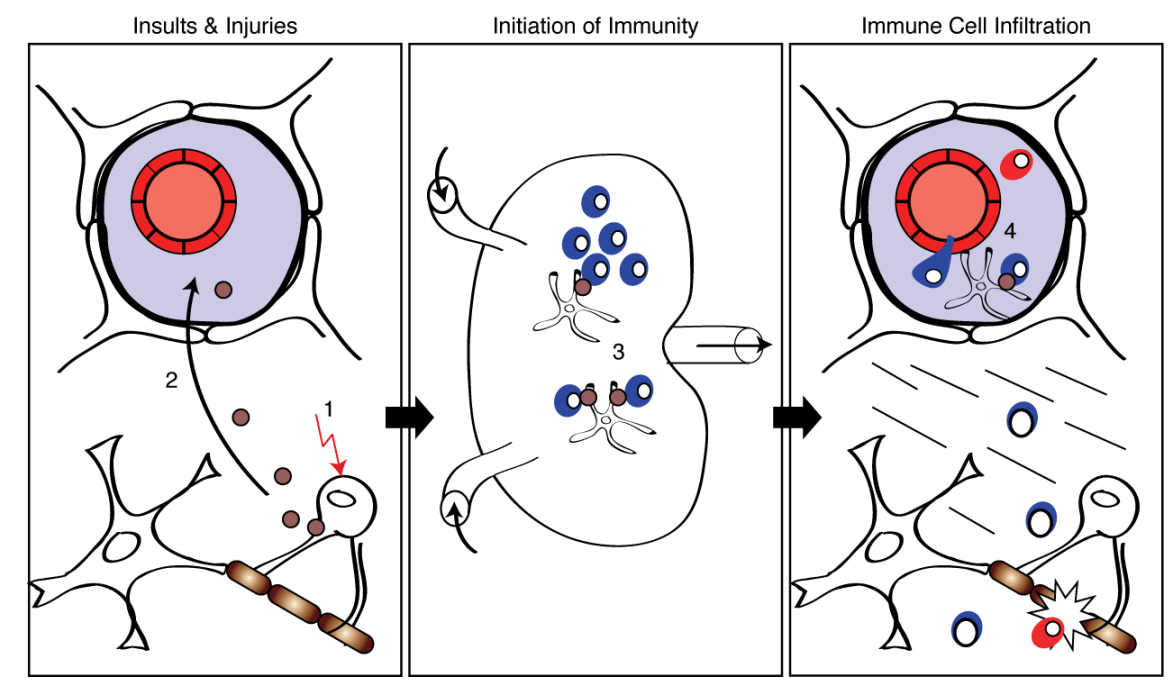

Figure 2. Model of initiation of CNS autoimmunity. 1) An initiating factor (red arrow) may cause damage/stress to oligodendrocytes (ODCs); 2) Antigens or danger signals released upon injury may be carried by interstitial fluid and drain into the CSF and either enter the blood circulation via arachnoid villi that protrude into the dural sinus or exit along the cranial nerves (in particular, the olfactory nerve) and reach the cervical lymph nodes (CLNs) via the nasal lymphatics; 3 ) In the CLNs, naïve myelin antigen-specific $T$ cells are primed by dendritic cells (DCs) and undergo clonal expansion. Primed $T$ cells are recruited to areas of CNS inflammation, as BBB endothelial cells now express the appropriate adhesion molecules and chemokines; 4) Once inside the PVS, the primed T cells are restimulated with their cognate antigen and are able to enter the CNS parenchyma to carry out their effector functions. 
other ideas of disease initiation. For example, primary autoimmunity is that it allows for the initial adaptive $\mathrm{ral} /$ bacterial infection) or self-antigens (e.g., from minor trauma), and therefore connects the standard model with immune response to be against either non-self (e.g., vi ODC death (as opposed to T cell-mediated death) itself may result in autoimmunity to myelin antigens exposed by death [120]. In seeming conflict with this idea, two groups have recently and independently shown that diphtheria toxin-induced ODC death does not elicit adaptive immune cell accumulation in the CNS $[121,122]$. In these studies, ODCs did not die by apoptosis (the form of cell death usually associated with MS and EAE) but instead underwent vacuolation-induced death, which is distinct from classical necrosis and apoptosis [123]. Additionally, change in the BBB is thought to be a critical and obligatory step for disease initiation [124], and indeed, contrast enhanced MRI has shown that disruption of the BBB is one of the earliest events in patients with MS [125]. However, BBB permeability was not altered in the transgenic animals used in either study, presumably due to lack of inflammation, thus precluding $\mathrm{T}$ cell entry. From these studies, we may conclude that vacuolation-induced ODC death per se does not induce autoimmunity; however, other types of cell death may.

Careful consideration must be given to the type of ODC death that is induced and whether it has the ability to initiate inflammation in the CNS (beyond microglia activation), which determines $\mathrm{T}$ cell recruitment and entry, as well as APC activation. These factors likely determine whether death induces autoimmunity or tolerance (or ignorance). ODC apoptosis, in particular, is important for EAE initiation, as inhibiting ODC apoptosis has been shown to attenuate the incidence and severity of disease $[37,126]$. (However, as a caveat, it could also mean that $\mathrm{T}$ cell-mediated effects are blocked.) For a long time apoptosis was considered to be an "immunologically silent" form of cell death, and so precisely how it could contribute to MS and EAE development was (and remains) unknown and is rather interesting. Work done by Matthew Albert and colleagues has demonstrated that DCs can acquire processed antigen from cells undergoing apoptosis and efficiently cross-present the antigen to CD8+ T cells [127-129]. In terms of CNS immunity, Meloni et al. demonstrated that DCs presenting antigens from apoptotic ODCs could stimulate IFN- $\gamma$ production and proliferation of MBP-specific T cell lines [130]. Additionally, DCs have been shown to mediate myelin epitope spreading in the CNS in vivo [71]; however, ODC cell death was not examined as a source of spread (or non-immunizing) antigen in this study. Thus, whether DCs acquire antigens from apoptotic ODCs and stimulate myelin-reactive $\mathrm{T}$ cells in vivo remains an open question.
In addition to dying cells being a source of immunogenic epitopes, they can potentially release internal damage-associated molecular patterns (DAMPs) and alarmins (reviewed in [131]). These signals might, in turn, activate and mobilize APCs. In this way, ODC death might be "sensed" by DCs and contribute to CNS autoimmunity. Several DAMPs were described by Kono and Rock [131], and here we present their association with MS/EAE in Table 2. While the DAMPs presented in Table 2 come from a variety of sources and have a variety of actions, to the best of our knowledge they are not released by ODC death. However, their role in directing DC subtype specification and, thus, in polarizing $\mathrm{T}$ cell responses against antigens released by ODC death are only beginning to be understood. For example, heat shock protein 70 has been shown to facilitate processing of MBP in murine fibroblasts made to express HLA-DR [132]. Future research will determine whether any of these or (as yet) undiscovered DAMPs are released from dying ODCs, or are just microenvironmental cues that contribute to the perfect "immunological storm".

One question that remains is why "normal" cell death results in tolerance and not autoimmunity. Recently, it has been shown that indoleamine 2,3-dioxygenase (IDO) can be induced in marginal zone macrophages and is necessary for tolerance to antigens from apoptotic cells [133]. Importantly, IDO-/- mice injected with apoptotic thymocytes resulted in increased autoantibody titers in the serum, as well as lethal autoimmunity due to renal failure [133]. Additionally, IDO has been shown to be upregulated in activated microglia from primary cell cultures [134]. These studies suggest that microglia may play a role in tolerance to self-antigens exposed by cellular apoptosis via IDO-dependent mechanisms. However, studies using MHC class I H-2D $\mathrm{D}^{\mathrm{b}}-/$ - bone marrow chimera mice have demonstrated that DCs are also important in establishing tolerance to CNS LCMV neoantigens [35]. In summary, the whole microenvironmenttal context of cell death likely determines whether CNS autoimmunity or tolerance results following injury.

\section{Regulation of CNS Immunity: The Role of Dendritic Cells}

One of the greatest challenges in MS research is finding ways to regulate aberrant immunity within the CNS. DCs are critical at this juncture and can be matured and imprinted by environmental cues both in vitro and in vivo to be functionally either immunogenic (stimulatory) or tolerogenic, which will be our focus in this section. Because of their functional plasticity, drugs that alter DC functionality will enable the therapeutic use of these cells (reviewed in [147]). There are two major DC subsets: classical myeloid DCs (mDCs) and plasmacytoid DCs (pDCs) that arise from a common-DC progenitor (reviewed in 
Table 2. DAMPs associated with MS/EAE pathology.

\begin{tabular}{|c|c|c|c|c|c|c|}
\hline DAMP & $\begin{array}{l}\text { Source or } \\
\text { localization }\end{array}$ & Activity in MS/EAE & $\begin{array}{l}\text { Suspected } \\
\text { autoantigen or } \\
\text { cross-reactivity }\end{array}$ & Receptor(s) & $\begin{array}{l}\text { Receptor } \\
\text { expression }\end{array}$ & Reference(s) \\
\hline HMGB1 & $\begin{array}{l}\text { microglia and } \\
\text { macrophage; CSF }\end{array}$ & unknown & - & $\begin{array}{l}\text { RAGE; TLR2; } \\
\text { TLR4 }\end{array}$ & $\begin{array}{l}\text { active lesions; } \\
\text { blood and CSF }\end{array}$ & [135] \\
\hline $\begin{array}{l}\text { Double- } \\
\text { stranded DNA }\end{array}$ & $\begin{array}{l}\text { intracellular; } \\
\text { anti-dsDNA } \\
\text { antibodies in MS } \\
\text { active plaque and } \\
\text { periplaque regions } \\
\text { and B cells in CSF }\end{array}$ & $\begin{array}{l}\text { anti-dsDNA antibodies } \\
\text { may promote MS lesion } \\
\text { formation }\end{array}$ & yes & N/A & N/A & [136] \\
\hline $\begin{array}{l}\text { Extracellular } \\
\text { nucloeotides } \\
\text { (e.g., ATP, } \\
\text { ADP, UTP, } \\
\text { UDP) }\end{array}$ & intracellular & $\begin{array}{l}\text { COX-2, iNOS, and } \\
\text { pro-inflammatory } \\
\text { cytokine production; } \\
\text { glial cell proliferation and } \\
\text { death }\end{array}$ & - & $\begin{array}{l}\mathrm{P} 2 \\
\text { receptors }\end{array}$ & $\begin{array}{l}\text { neurons, glial } \\
\text { cells, Schwann } \\
\text { cells, } \\
\text { CNS-infiltrating } \\
\text { leukocytes }\end{array}$ & $\begin{array}{l}\text { reviewed in } \\
{[139]}\end{array}$ \\
\hline Adenosine & intracellular & anti-inflammatory & - & $\begin{array}{l}\mathrm{P} 1 \\
\text { receptors }\end{array}$ & $\begin{array}{l}\text { neurons, } \\
\text { microglia, } \\
\text { astrocytes, } \\
\text { leukocytes }\end{array}$ & $\begin{array}{l}\text { reviewed in } \\
{[139]}\end{array}$ \\
\hline \multirow[t]{2}{*}{$\begin{array}{l}\text { Heat-shock } \\
\text { proteins }\end{array}$} & intracellular & $\begin{array}{l}\text { Hsp-CNP peptide can } \\
\text { protect against or } \\
\text { aggravate EAE, } \\
\text { depending on Th1 or Th2 } \\
\text { immune response pattern }\end{array}$ & $\begin{array}{l}\text { cross-reactivity } \\
\text { between } \\
\text { mycobacterial } \\
\text { Hsp65 and } \\
\text { CNP153-164 }\end{array}$ & N/A & $\mathrm{N} / \mathrm{A}$ & {$[140]$} \\
\hline & $\begin{array}{l}\text { intracellular; binds to } \\
\text { certain MBP peptides } \\
\text { in vitro }\end{array}$ & $\begin{array}{l}\text { Hsp } 70 \text { facilitates } \\
\text { autoantigen processing }\end{array}$ & - & N/A & N/A & [132] \\
\hline $\mathrm{S} 100$ proteins & $\begin{array}{l}\text { astrocytes and } \\
\text { subpopulation of } \\
\text { ODCs }\end{array}$ & unknown & - & - & - & {$[141]$} \\
\hline $\begin{array}{l}\text { Fibronectin } \\
\text { /Fibrinogen }\end{array}$ & $\begin{array}{l}\text { ECM/plasma; } \\
\text { primarily localized to } \\
\text { microvessel walls } \\
\text { (fibronectin) and } \\
\text { lumen (fibrinogen), } \\
\text { but also on } \\
\text { mononuclear cells and } \\
\text { extracellular deposits }\end{array}$ & $\begin{array}{l}\text { facilitate mononuclear } \\
\text { cell adhesion and } \\
\text { migration, myelin } \\
\text { phagocytosis, and } \\
\text { breakdown of BBB; } \\
\text { fibronectin can inhibit } \\
\text { myelination }\end{array}$ & - & $\begin{array}{l}\text { fibronectin } \\
\text { receptor }\end{array}$ & macrophages & {$[142-145]$} \\
\hline $\begin{array}{l}\text { Hyaluronan } \\
\text { (HA) }\end{array}$ & $\begin{array}{l}\text { ECM component; } \\
\text { secreted by astrocytes } \\
\text { and microglia }\end{array}$ & $\begin{array}{l}\text { LMW HA inhibits OPC } \\
\text { maturation via TLR2 }\end{array}$ & - & CD44; TLR2 & ODCs; T cells & [146-148] \\
\hline
\end{tabular}




\section{Continued}

\begin{tabular}{|c|c|c|c|c|c|c|}
\hline $\begin{array}{l}\text { Heparan sulfate } \\
\text { (proteoglycan) }\end{array}$ & $\begin{array}{l}\text { ECM component } \\
\text { of basement } \\
\text { membrane }\end{array}$ & $\begin{array}{l}\text { cleavage by heparanase } \\
\text { facilitates immune cell } \\
\text { migration through ECM }\end{array}$ & - & $\begin{array}{l}\text { may act as a } \\
\text { chemokine } \\
\text { reservoir }\end{array}$ & N/A & {$[149,150]$} \\
\hline $\begin{array}{l}\text { Laminin- and } \\
\text { collagen-derived } \\
\text { peptides }\end{array}$ & $\begin{array}{l}\text { ECM components } \\
\text { of basement } \\
\text { membrane }\end{array}$ & $\begin{array}{l}\text { cleavage by matrix } \\
\text { metalloproteinases } \\
\text { facilitates immune cell } \\
\text { migration through ECM }\end{array}$ & - & $\begin{array}{l}\text { integrins (e.g., } \\
\text { VLA-1, } \\
\text { VLA-2, } \\
\text { VLA-6) }\end{array}$ & $\begin{array}{l}\text { lymphocytes } \\
\text { and monocytes }\end{array}$ & {$[150,151]$} \\
\hline $\begin{array}{l}\text { Elastin-derived } \\
\text { peptides }\end{array}$ & $\begin{array}{l}\text { component of the } \\
\text { dura mater; } \\
\text { degraded by } \\
\text { macrophage } \\
\text { metalloelastase }\end{array}$ & unknown & - & $\begin{array}{l}\text { elastin recep- } \\
\text { tor }\end{array}$ & $\begin{array}{l}\text { peripheral blood } \\
\text { lymphocytes }\end{array}$ & [152-154] \\
\hline Galectins & $\begin{array}{l}\text { microglia and } \\
\text { macrophage, } \\
\text { astrocytes, } \\
\text { endothelial cells, } \\
\text { DCs }\end{array}$ & $\begin{array}{l}\text { induction of tolerogenic } \\
\text { DCs; negative } \\
\text { regulation of effector T } \\
\text { cells }\end{array}$ & - & $\begin{array}{l}\text { GM1 } \\
\text { ganglioside; } \\
\text { glycoproteins }\end{array}$ & - & [155-160] \\
\hline
\end{tabular}

[161]). These subsets can be distinguished by differences in surface marker expression. $\mathrm{mDCs}$ are $\mathrm{CD} 11 \mathrm{c}^{+} \mathrm{CD} 11 \mathrm{~b}^{+}$. In mice, $\mathrm{pDCs}$ are $\mathrm{CD} 11 \mathrm{c}^{\text {low }} \mathrm{CD} 11 \mathrm{~b}^{-} \mathrm{B} 220^{+} \mathrm{Ly}_{6 \mathrm{C}^{+}}$, whereas in humans, $\mathrm{pDCs}$ are $\mathrm{CD} 11 \mathrm{c}^{-} \mathrm{CD} 4^{+} \mathrm{CD} 45 \mathrm{RA}^{+}$ $\mathrm{IL}-3 \mathrm{R} \alpha^{+} \mathrm{ILT2}^{+} \mathrm{ILT1}^{-}$(reviewed in [162]). Additionally, many more sub-subsets of $\mathrm{mDCs}$ have been found in lymphoid and non-lymphoid tissues [161]. Distinct DC subsets have been shown to accumulate in the CNS in response to different environmental stimuli (bacterial, viral, DAMP), and thereby promote the appropriate adaptive immune response (reviewed in [163]). As we will also discuss, pDCs may have a critical role in promoting protection against CNS autoimmunity. It will only be mentioned here in passing that mechanisms internal to the DC itself also contribute to immune regulation by keeping the DC in an immature, non-stimulatory state [164]. This was demonstrated recently, as DCs lacking nuclear factor- $\kappa \mathrm{B} 1$ (NF- $\kappa \mathrm{B} 1)$ were able to induce autoimmune diabetes as a result of unchecked production of TNF- $\alpha$, which promoted cytotoxic CD8+ T cell production of the apoptosis-inducing enzyme granzyme $\mathrm{B}$ [164]. Finally, other cell types are involved in the suppression of CNS autoimmune responses, such as regulatory $\mathrm{T}$ cells (Tregs) and myeloid-derived suppressor cells (which are now beginning to be recognized for their contribution to the resolution of CNS autoimmunity [103]), but they will not be discussed further.

\subsection{Environmental Imprinting of Myeloid DCs Affects CNS Disease Outcome}

\subsubsection{Stimulatory Roles for $\mathrm{mDCs}$}

DCs accumulate in the CNS when there is inflammation, and so they are thought to be important for disease development and maintenance. We have previously shown that intracerebrally injected, antigen-loaded $\mathrm{mDCs}$ can migrate to peripheral lymphoid tissues and induce the homing of responder $\mathrm{T}$ cells to the CNS $[26,100,165]$. We found that intracerebral delivery of $\mathrm{MOG}_{35-55}$-pulsed DCs lead to an increase in the frequency of activated $\mathrm{MOG}_{35-55}$-specific (i.e., 2D2) effector T cells in the CNS, which hastened the onset and increased the severity of EAE [165]. Importantly, this effect was dependent upon the functional status of the DCs. Mice intracerebrally injected with stimulatory (i.e., LPS-stimulated) DCs had more severe EAE and increased CNS accumulation of pathogenic Th17 cells, whereas those that received tolerogenic (i.e., TNF- $\alpha$-stimulated) DCs had a much lower disease incidence, as well as delayed onset and decreased severity; tolerogenic DCs promoted IL-10 production in the periphery and suppressed IL-17 production in the CNS. Our work therefore demonstrates that depending on the functional status of DCs, the disease outcome can be better or worse. This illustrates the capacity of DC functional status/phenotype to determine the resulting adaptive immune response. Similarly, the disease environment within the CNS also determines the functional state of DCs. Deshpande et al. showed that $\mathrm{CD} 11 \mathrm{c}+\mathrm{mDCs}$ isolated right after EAE onset were better at promoting $2 \mathrm{D} 2 \mathrm{~T}$ cell activation and were markedly more mature (i.e., displaying increased levels of costimulatory molecules and the lymphoid tissue homing receptor CCR7) than those isolated right before disease remission [166]. Interestingly, while the $\mathrm{mDCs}$ isolated early in EAE supported differentiation of both Th1 and Th17 T cells, they simultaneously also supported Treg 
suppression of 2D2 activation [166]. Collectively, these studies show that, depending on how they are imprinted in vitro or in vivo, mDCs may either facilitate or suppress ongoing inflammation.

The precise mechanisms by which DCs regulate CNS disease processes are beginning to be unraveled. While DCs are known for their unique ability to determine the lineage commitment, and thus effector function, of naïve $\mathrm{T}$ cells, effector $\mathrm{T}$ cells may also participate in perpetuating their own lineage by directing monocytes to differentiate into particular lineage-promoting DC subtypes [167]. Particular attention has been paid to the differentiation of Th17 cells, which are regarded as one of the main pathogenic subsets involved in MS and EAE disease initiation. A recent study showed that Th17 production of GM-CSF drove $\mathrm{mDC}$ production of IL-23, which, in turn, had a positive feedback on Th17 lineage commitment [168]. Thus, by assisting with the differentiation of this pathogenic population, mDCs play a critical role in stimulating ongoing inflammation and autoimmunity. It has been shown that the ability of DCs to produce IL-23 in response to GM-CSF depends on their expression of CC chemokine receptor 4 (CCR4), which is required for EAE initiation [169]. Finally, it was also demonstrated that, $\mathrm{mDCs}$, compared to $\mathrm{pDCs}$ and CNS macrophages, induce Th17 polarization of naïve CD4+ T cells specific for non-EAE-inducing epitope in the REAE mouse model, thereby facilitating epitope spreading [112]. Thus, there is strong evidence that mDCs contribute to CNS autoimmune disease initiation and relapse by regulating the development of pathogenic Th17 cells.

\subsubsection{Tolerogenic Roles for mDCs}

There are many soluble factors that can promote the tolerogenic phenotype of $\mathrm{mDCs}$ within the CNS and contribute to the prevention and/or resolution of CNS autoimmunity, including anti-inflammatory cytokines (e.g., IL-10; TGF- $\beta$ ), neuropeptides and hormones (e.g., vasoactive intestinal peptide, VIP; $\alpha$-melanocyte-stimulating hormone, $\alpha$-MSH), as well as new molecular candidates that need to be considered (e.g., galectins). However, we will only discuss a few examples here. For a more thorough review of tolerogenic DCs, see [170].

Anti-inflammatory cytokines are well known for their ability to promote tolerogenic immune responses by competing effectively with pro-inflammatory cytokines in an inflammatory setting; generally, they are thought to activate Th2 and Treg cells and/or suppress Th1 cells and inhibit pro-inflammatory cytokine synthesis (reviewed in [171]). However, as recent evidence indicates, anti-inflammatory cytokines may also contribute to tolerance in normal settings by preventing self-reactive $\mathrm{T}$ cell activetion [172]. Laouar et al. sought a mechanistic explanation for the protective effect of TGF- $\beta$ against EAE. Us- ing a specialized set of bone marrow chimeric mice, they were able to demonstrate that inhibiting TGF- $\beta$-mediated signaling specifically in DCs could promote the development of spontaneous and severe EAE that was accompanied by general features of inflammation (e.g., microglia activation and increased levels of mRNA for proinflammatory cytokines), as well as CD4+ T cell accumulation in the CNS [172]. Interestingly, the majority of MHC class II+ cells observed in the spinal cord were CD45low, indicating that they were microglia. This suggests that DCs exert their tolerogenic influence outside the CNS. These results indicate that intact TGF- $\beta$ R signaling in DCs promotes suppression of autoimmunity, perhaps by keeping resting DCs in an immature state.

Apart from cytokines, VIP, as mentioned above, is a neuropeptide that induces tolerogenic function in $\mathrm{mDCs}$ [173]. Lentiviral vectors were recently used to engineer DCs to express VIP [174]. In this study, mice that received a single injection of VIP-expressing DCs were protected against disease development in both relapsing and primary progressive models of EAE. Interestingly, the VIP-expressing DCs were found to accumulate in non-lymphoid peripheral tissues (e.g., liver and lung) in higher numbers than in lymphoid tissues, a migration pattern somewhat unexpected in the acute phase of EAE. It would be interesting to see whether the anti-inflammatory cytokine profile observed in total RNA isolated from the spinal cord at the peak of disease was due to VIP-expressing DCs exerting their tolerogenic effects systemically or within the CNS. However, the clear suppression of EAE observed in two disease models illustrates that DCs may be used to deliver anti-inflammatory agents for use in the treatment of CNS inflammatory diseases.

As a final example, another soluble factor that works as an anti-inflammatory cytokine in the traditional sense is galectin-1 (Gal1), a glycoprotein that is a member of a family of lectins. It promotes a tolerogenic phenotype in DCs during their differentiation process. DCs differentiated in presence of Gall or that express Gall endogenously were shown to suppress the chronic phase of $\mathrm{MOG}_{35-55}$-induced EAE, inhibit $\mathrm{T}$ cell proliferation and pro-inflammatory cytokine production, and increase IL-10 production via an IL-27-dependent pathway [102]. They also found that Gall levels were the highest at peak and chronic phases of EAE. Additionally, immature, but not mature, mDCs produced high levels of Gall. When subsequently cultured with tolerogenic stimuli (such as VIP, IL-10, vitamin D3, and also apoptotic cells) these immature mDCs significantly increased Gall expression, whereas pro-inflammatory stimuli had the opposite effect. This study is interesting because it shows that as the inflammatory milieu changes within the CNS, the maturation status of DCs may render them more or less suscep- 
tible to tolerogenic environmental factors, thereby influencing their contribution to disease resolution.

\subsection{Plasmacytoid DCs and Their Contribution to Regulation of CNS Autoimmunity}

While pDCs from the inflamed CNS are not as efficient as $\mathrm{mDCs}$ at priming naïve or effector PLP peptide-specific $T$ cells [175], they seem to play a crucial role in negatively regulating EAE [175-177]. However, the mechanisms by which they do this are only beginning to be elucidated. In order to directly address the question of whether protection against severe EAE was the result of $\mathrm{T}$ cell priming by $\mathrm{pDCs}$, Irla et al. used mutant chimeric mice lacking MHC class II only in pDCs to show that pDCs facilitated Treg priming and expansion in the draining lymph nodes of mice with EAE in an antigen-specific fashion [177]. A different mechanism was proposed by Bailey-Bucktrout et al. [176], who found that pDCs exerted their immunoregulatory effects by suppressing $\mathrm{mDC}$-induced $\mathrm{CD} 4+\mathrm{T}$ cell production of IFN- $\gamma$, IL-17, and IL-10 cytokines, and not through IDO-mediated inhibition of T cells. However, they did observe that blocking IDO resulted in slightly increased levels of IFN- $\gamma$ and IL-17 when CD4+ T cells were stimulated with mDCs. This could be due to the inhibition of the natural Treg subpopulation [178], and would also support that CNS mDCs might promote Treg proliferation in the CNS, which was not found to be impaired in the CNS of mutant chimeric mice in the Irla et al. study [177].

\section{Conclusion}

The CNS is a precious tissue in which there must be a fine balance between immune surveillance (i.e., immune cell admittance) and privilege (i.e., immune cell exclusion). We have discussed that while routine surveillance of the subarachnoid space by $\mathrm{T}$ cells does occur in the healthy CNS, increased surveillance results in autoimmunity. While EAE initiation has been shown to be dependent on DCs, it is still unknown where initial $\mathrm{T}$ cell priming occurs. Based on our discussion, disease initiation likely involves antigen drainage and priming of naive $\mathrm{T}$ cells in the CLNs, but disease progression likely involves local restimulation by DCs and (to a lesser extent) perivascular macrophages within the PVS and ectopic lymphoid structures in the SAS. This is an ongoing field of investigation. Several theories of CNS autoimmune disease initiation in humans have been presented, including whether primary death of myelin-producing cells in the CNS stimulates autoimmunity, which remains controversial. Whether cell death induces immunity, tolerance, or ignorance is determined by the entire micro- environmental context, which induces different functional phenotypes of DCs. Therefore, DCs are probably master regulators of the autoimmune disease process in CNS.

\section{Acknowledgements}

The authors would like to thank Benjamin D. Clarkson for critically reviewing this manuscript. This work was funded by NIH/NIGMS grant T32-GM007507 (Neuroscience Training Program) and NIH grant R01-NS37570 (Z. Fabry).

\section{REFERENCES}

[1] R. R. Caspi, "Immunotherapy of Autoimmunity and Cancer: The Penalty for Success," Nature Reviews Immunology, Vol. 8, No. 12, 2008, pp. 970-976. doi: $10.1038 /$ nri2438

[2] O. Stuve, C. M. Marra, K. R. Jerome, L. Cook, P. D. Cravens, S. Cepok, E. M. Frohman, J. T. Phillips, G. Arendt, B. Hemmer, N. L. Monson and M. K. Racke, "Immune Surveillance in Multiple Sclerosis Patients Treated with Natalizumab," Annals of Neurology, Vol. 59, No. 5, 2006, pp. 743-747. doi:10.1002/ana.20858

[3] I. Galea, I. Bechmann and V. H. Perry, "What Is Immune Privilege (Not)?" Trends in Immunology, Vol. 28, No. 1, 2007, pp. 12-18. doi:10.1016/j.it.2006.11.004

[4] B. Engelhardt and C. Coisne, "Fluids and Barriers of the CNS Establish Immune Privilege by Confining Immune Surveillance to a Two-Walled Castle Moat Surrounding the CNS Castle," Fluids and Barriers of the CNS, Vol. 8, No. 1, 2011, p. 4. doi:10.1186/2045-8118-8-4

[5] B. T. Hawkins and T. P. Davis, "The Blood-Brain Barrier/Neurovascular Unit in Health and Disease," Pharmacological Reviews, Vol. 57, No. 2, 2005, pp. 173-185. doi:10.1124/pr.57.2.4

[6] P. Kivisakk, D. J. Mahad, M. K. Callahan, C. Trebst, B. Tucky, T. Wei, L. Wu, E. S. Baekkevold, H. Lassmann, S. M. Staugaitis, J. J. Campbell and R. M. Ransohoff, "Human Cerebrospinal Fluid Central Memory CD4+ T Cells: Evidence for Trafficking through Choroid Plexus and Meninges via P-Selectin," Proceedings of the National Academy of Sciences of the United States of America, Vol. 100, No. 14, 2003, pp. 8389-8394. doi:10.1073/pnas. 1433000100

[7] J. Goverman, "Autoimmune T Cell Responses in the Central Nervous System," Nature Reviews Immunology, Vol. 9, No. 6, 2009, pp. 393-407. doi:10.1038/nri2550

[8] P. Kivisakk, J. Imitola, S. Rasmussen, W. Elyaman, B. Zhu, R. M. Ransohoff and S. J. Khoury, "Localizing Central Nervous System Immune Surveillance: Meningeal Antigen-Presenting Cells Activate T Cells during Experimental Autoimmune Encephalomyelitis," Annals of Neurology, Vol. 65, No. 4, 2009, pp. 457-469.

doi:10.1002/ana.21379

[9] B. K. Kleinschmidt-DeMasters and K. L. Tyler, "Progressive Multifocal Leukoencephalopathy Complicating 
treatment with Natalizumab and Interferon Beta-1a for Multiple Sclerosis," The New England Journal of Medicine, Vol. 353, No. 4, 2005, pp. 369-374.

doi:10.1056/NEJMoa051782

[10] A. Langer-Gould, S. W. Atlas, A. J. Green, A. W. Bollen and D. Pelletier, "Progressive Multifocal Leukoencephalopathy in a Patient Treated with Natalizumab," The New England Journal of Medicine, Vol. 353, No. 4, 2005, pp. 375-381. doi:10.1056/NEJMoa051847

[11] G. Van Assche, M. Van Ranst, R. Sciot, B. Dubois, S. Vermeire, M. Noman, J. Verbeeck, K. Geboes, W. Robberecht and P. Rutgeerts, "Progressive Multifocal Leukoencephalopathy after Natalizumab Therapy for Crohn's Disease," The New England Journal of Medicine, Vol. 353, No. 4, 2005, pp. 362-368. doi:10.1056/NEJMoa051586

[12] A. Reboldi, C. Coisne, D. Baumjohann, F. Benvenuto, D. Bottinelli, S. Lira, A. Uccelli, A. Lanzavecchia, B. Engelhardt and F. Sallusto, "C-C Chemokine Receptor 6Regulated Entry of TH-17 Cells into the CNS through the Choroid Plexus Is Required for the Initiation of EAE," Nature Immunology, Vol. 10, No. 5, 2009, pp. 514-523. doi:10.1038/ni.1716

[13] C. L. Langrish, Y. Chen, W. M. Blumenschein, J. Mattson, B. Basham, J. D. Sedgwick, T. McClanahan, R. A. Kastelein and D. J. Cua, "IL-23 Drives a Pathogenic T Cell Population That Induces Autoimmune Inflammation," The Journal of Experimental Medicine, Vol. 201, No. 2, 2005, pp. 233-240. doi:10.1084/jem.20041257

[14] A. Peters, L. A. Pitcher, J. M. Sullivan, M. Mitsdoerffer, S. E. Acton, B. Franz, K. Wucherpfennig, S. Turley, M. C. Carroll, R. A. Sobel, E. Bettelli and V. K. Kuchroo, "Th17 Cells Induce Ectopic Lymphoid Follicles in Central Nervous System Tissue Inflammation," Immunity, Vol. 35, No. 6, 2011, pp. 986-996. doi:10.1016/j.immuni.2011.10.015

[15] R. Magliozzi, S. Columba-Cabezas, B. Serafini and F. Aloisi, "Intracerebral Expression of CXCL13 and BAFF Is Accompanied by Formation of Lymphoid Follicle-Like Structures in the Meninges of Mice with Relapsing Experimental Autoimmune Encephalomyelitis," Journal of Neuroimmunology, Vol. 148, No. 1-2, 2004, pp. 11-23. doi:10.1016/j.jneuroim.2003.10.056

[16] R. Magliozzi, O. Howell, A. Vora, B. Serafini, R. Nicholas, M. Puopolo, R. Reynolds and F. Aloisi, "Meningeal B-Cell Follicles in Secondary Progressive Multiple Sclerosis Associate with Early Onset of Disease and Severe Cortical Pathology," Brain, Vol. 130, No. 4, 2007, pp. 1089-1104.

[17] B. Serafini, B. Rosicarelli, R. Magliozzi, E. Stigliano and F. Aloisi, "Detection of Ectopic B-Cell Follicles with Germinal Centers in the Meninges of Patients with Secondary Progressive Multiple Sclerosis," Brain Pathology, Vol. 14, No. 2, 2004, pp. 164-174. doi:10.1111/j.1750-3639.2004.tb00049.x

[18] A. P. Byrnes, J. E. Rusby, M. J. Wood and H. M. Charlton, "Adenovirus Gene Transfer Causes Inflammation in the Brain," Neuroscience, Vol. 66, No. 4, 1995, pp. 10151024. doi:10.1016/0306-4522(95)00068-T

[19] M. K. Matyszak, "Inflammation in the CNS: Balance between Immunological Privilege and Immune Responses," Progress in Neurobiology, Vol. 56, No. 1, 1998, pp. 19-35. doi:10.1016/S0301-0082(98)00014-8

[20] M. K. Matyszak and V. H. Perry, "Demyelination in the Central Nervous System Following a Delayed-Type Hypersensitivity Response to Bacillus Calmette-Guerin," Neuroscience, Vol. 64, No. 4, 1995, pp. 967-977. doi:10.1016/0306-4522(94)00448-E

[21] M. K. Matyszak, M. J. Townsend and V. H. Perry, "U1trastructural Studies of an Immune-Mediated Inflammatory Response in the CNS Parenchyma Directed against a Non-CNS Antigen," Neuroscience, Vol. 78, No. 2, 1997, pp. 549-560. doi:10.1016/S0306-4522(96)00578-7

[22] H. F. Cserr and P. M. Knopf, "Cervical Lymphatics, the Blood-Brain Barrier and the Immunoreactivity of the Brain: A New View," Immunology Today, Vol. 13, No. 12, 1992, pp. 507-512. doi:10.1016/0167-5699(92)90027-5

[23] S. Yamada, M. DePasquale, C. S. Patlak and H. F. Cserr, "Albumin Outflow into Deep Cervical Lymph from Different Regions of Rabbit Brain," American Journal of Physiology, Vol. 261, No. 4, 1991, pp. H1197-H1204.

[24] L. B. Gordon, P. M. Knopf and H. F. Cserr, "Ovalbumin Is More Immunogenic When Introduced into Brain or Cerebrospinal Fluid than Into Extracerebral Sites," Journal of Neuroimmunology, Vol. 40, No. 1, 1992, pp. 81-87. doi:10.1016/0165-5728(92)90215-7

[25] C. Harling-Berg, P. M. Knopf, J. Merriam and H. F. Cserr, "Role of Cervical Lymph Nodes in the Systemic Humoral Immune Response to Human Serum Albumin Microinfused into Rat Cerebrospinal Fluid," Journal of Neuroimmunology, Vol. 25, No. 2-3, 1989, pp. 185-193. doi:10.1016/0165-5728(89)90136-7

[26] J. Karman, C. Ling, M. Sandor and Z. Fabry, "Initiation of Immune Responses in Brain Is Promoted by Local Dendritic Cells," The Journal of Immunology, Vol. 173, No. 4, 2004, pp. 2353-2361.

[27] C. Ling, M. Sandor and Z. Fabry, "In Situ Processing and Distribution of Intracerebrally Injected OVA in the CNS," Journal of Neuroimmunology, Vol. 141, No. 1-2, 2003, pp. 90-98. doi:10.1016/S0165-5728(03)00249-2

[28] C. Ling, M. Sandor, M. Suresh and Z. Fabry, "Traumatic Injury and the Presence of Antigen Differentially Contribute to T-Cell Recruitment in the CNS," The Journal of Neuroscience, Vol. 26, No. 3, 2006, pp. 731-741. doi:10.1523/JNEUROSCI.3502-05.2006

[29] Z. Qing, D. Sewell, M. Sandor and Z. Fabry, “AntigenSpecific T Cell Trafficking into the Central Nervous System," Journal of Neuroimmunology, Vol. 105, No. 2, 2000, pp. 169-178. doi:10.1016/S0165-5728(99)00265-9

[30] M. Sanchez-Ruiz, L. Wilden, W. Muller, W. Stenzel, A. Brunn, H. Miletic, D. Schluter and M. Deckert, "Molecular Mimicry between Neurons and an Intracerebral Pathogen Induces a CD8 T Cell-Mediated Autoimmune Disease," The Journal of Immunology, Vol. 180, No. 12, 2008, pp. 8421-8433.

[31] T. Scheikl, B. Pignolet, C. Dalard, S. Desbois, D. Raison, M. Yamazaki, A. Saoudi, J. Bauer, H. Lassmann, H. Hardin-Pouzet and R. S. Liblau, "Cutting Edge: Neuronal 
Recognition by CD8 T Cells Elicits Central Diabetes Insipidus," The Journal of Immunology, Vol. 188, No. 10, 2012, pp. 4731-4735. doi:10.4049/jimmunol.1102998

[32] A. Cornet, T. C. Savidge, J. Cabarrocas, W. L. Deng, J. F. Colombel, H. Lassmann, P. Desreumaux and R. S. Liblau, "Enterocolitis Induced by Autoimmune Targeting of Enteric Glial Cells: A Possible Mechanism in Crohn's Disease?" Proceedings of the National Academy of Sciences of the United States of America, Vol. 98, No. 23, 2001, pp. 13306-13311. doi:10.1073/pnas.231474098

[33] Y. Cao, C. Toben, S. Y. Na, K. Stark, L. Nitschke, A. Peterson, R. Gold, A. Schimpl and T. Hunig, "Induction of Experimental Autoimmune Encephalomyelitis in Transgenic Mice Expressing Ovalbumin in Oligodendrocytes," European Journal of Immunology, Vol. 36, No. 1, 2006, pp. 207-215. doi:10.1002/eji.200535211

[34] A. Saxena, J. Bauer, T. Scheikl, J. Zappulla, M. Audebert, S. Desbois, A. Waisman, H. Lassmann, R. S. Liblau and L. T. Mars, "Cutting Edge: Multiple Sclerosis-Like Lesions Induced by Effector CD8 T Cells Recognizing a Sequestered Antigen on Oligodendrocytes," The Journal of Immunology, Vol. 181, No. 3, 2008, pp. 1617-1621.

[35] A. Schildknecht, H. C. Probst, K. D. McCoy, I. Miescher, C. Brenner, D. P. Leone, U. Suter, P. S. Ohashi and M. van den Broek, "Antigens Expressed by Myelinating Glia Cells Induce Peripheral Cross-Tolerance of Endogenous CD8+ T Cells," European Journal of Immunology, Vol. 39, No. 6, 2009, pp. 1505-1515. doi:10.1002/eji.200839019

[36] J. Jung and M. Michalak, "Cell Surface Targeting of Myelin Oligodendrocyte Glycoprotein (MOG) in the Absence of Endoplasmic Reticulum Molecular Chaperones," Biochimica et Biophysica Acta, Vol. 1813, No. 5, 2011, pp. 1105-1110. doi:10.1016/j.bbamcr.2010.12.014

[37] N. Hovelmeyer, Z. Hao, K. Kranidioti, G. Kassiotis, T. Buch, F. Frommer, L. von Hoch, D. Kramer, L. Minichiello, G. Kollias, H. Lassmann and A. Waisman, "Apoptosis of Oligodendrocytes via Fas and TNF-R1 Is a Key Event in the Induction of Experimental Autoimmune Encephalomyelitis," The Journal of Immunology, Vol. 175, No. 9, 2005, pp. 5875-5884.

[38] E. Barbarese, C. Barry, C. H. Chou, D. J. Goldstein, G. A. Nakos, R. Hyde-DeRuyscher, K. Scheld and J. H. Carson, "Expression and Localization of Myelin Basic Protein in Oligodendrocytes and Transfected Fibroblasts," Journal of Neurochemistry, Vol. 51, No. 6, 1988, pp. 1737-1745. doi:10.1111/j.1471-4159.1988.tb01153.x

[39] S. Y. Na, Y. Cao, C. Toben, L. Nitschke, C. Stadelmann, R. Gold, A. Schimpl and T. Hunig, "Naive CD8 T-Cells Initiate Spontaneous Autoimmunity to a Sequestered Model Antigen of the Central Nervous System," Brain, Vol. 131, No. 9, 2008, pp. 2353-2365.

[40] V. S. Schwob, H. B. Clark, D. Agrawal and H. C. Agrawal, "Electron Microscopic Immunocytochemical Localization of Myelin Proteolipid Protein and Myelin Basic Protein to Oligodendrocytes in Rat Brain during Myelination," Journal of Neurochemistry, Vol. 45, No. 2, 1985, pp. 559-571. doi:10.1111/j.1471-4159.1985.tb04024.x

[41] D. P. Leone, S. Genoud, S. Atanasoski, R. Grausenburger,
P. Berger, D. Metzger, W. B. Macklin, P. Chambon and U. Suter, "Tamoxifen-Inducible Glia-Specific Cre Mice for Somatic Mutagenesis in Oligodendrocytes and Schwann Cells," Molecular and Cellular Neuroscience, Vol. 22, No. 4, 2003, pp. 430-440. doi:10.1016/S1044-7431(03)00029-0

[42] M. Jeffrey, G. A. Wells and A. W. Bridges, "An Immunohistochemical Study of the Topography and Cellular Localization of Three Neural Proteins in the Sheep Nervous System," Journal of Comparative Pathology, Vol. 103, No. 1, 1990, pp. 23-35. doi:10.1016/S0021-9975(08)80132-6

[43] P. J. Marangos and D. E. Schmechel, "Neuron Specific Enolase, a Clinically Useful Marker for Neurons and Neuroendocrine Cells," Annual Review of Neuroscience, Vol. 10, 1987, pp. 269-295.

doi:10.1146/annurev.ne.10.030187.001413

[44] K. Shen, M. N. Teruel, K. Subramanian and T. Meyer, "CaMKIIbeta Functions as an F-Actin Targeting Module That Localizes CaMKIIalpha/Beta Heterooligomers to Dendritic Spines," Neuron, Vol. 21, No. 3, 1998, pp. 593-606. doi:10.1016/S0896-6273(00)80569-3

[45] E. Casanova, S. Fehsenfeld, T. Mantamadiotis, T. Lemberger, E. Greiner, A. F. Stewart and G. Schutz, "A CamKIIalpha iCre BAC Allows Brain-Specific Gene Inactivation," Genesis, Vol. 31, No. 1, 2001, pp. 37-42. doi:10.1002/gene. 1078

[46] A. J. Slavin, J. M. Soos, O. Stuve, J. C. Patarroyo, H. L. Weiner, A. Fontana, E. K. Bikoff and S. S. Zamvil, "Requirement for Endocytic Antigen Processing and Influence of Invariant Chain and H-2M Deficiencies in CNS Autoimmunity," The Journal of Clinical Investigation, Vol. 108, No. 8, 2001, pp. 1133-1139.

[47] M. L. Krakowski and T. Owens, "Naive T Lymphocytes Traffic to Inflamed Central Nervous System, but Require Antigen Recognition for Activation," European Journal of Immunology, Vol. 30, No. 4, 2000, pp. 1002-1009. doi:10.1002/(SICI) 1521-4141(200004)30:4<1002::AID-I MMU1002>3.0.CO;2-2

[48] M. K. Matyszak and V. H. Perry, "The Potential Role of Dendritic Cells in Immune-Mediated Inflammatory Diseases in the Central Nervous System," Neuroscience, Vol. 74, No. 2, 1996, pp. 599-608. doi:10.1016/0306-4522(96)00160-1

[49] P. G. McMenamin, "Distribution and Phenotype of Dendritic Cells and Resident Tissue Macrophages in the Dura Mater, Leptomeninges, and Choroid Plexus of the Rat Brain as Demonstrated in Whole Mount Preparations," The Journal of Comparative Neurology, Vol. 405, No. 4, 1999, pp. 553-562. doi:10.1002/(SICI)1096-9861(19990322)405:4<553::AID -CNE8>3.0.CO;2-6

[50] N. Anandasabapathy, G. D. Victora, M. Meredith, R. Feder, B. Dong, C. Kluger, K. Yao, M. L. Dustin, M. C. Nussenzweig, R. M. Steinman and K. Liu, "Flt3L Controls the Development of Radiosensitive Dendritic Cells in the Meninges and Choroid Plexus of the Steady-State Mouse Brain," The Journal of Experimental Medicine, Vol. 208, No. 8, 2011, pp. 1695-1705.

doi:10.1084/jem.20102657 
[51] H. G. Fischer, U. Bonifas and G. Reichmann, "Phenotype and Functions of Brain Dendritic Cells Emerging during Chronic Infection of Mice with Toxoplasma Gondii," The Journal of Immunology, Vol. 164, No. 9, 2000, pp. 48264834.

[52] B. Serafini, S. Columba-Cabezas, F. Di Rosa and F. Aloisi, "Intracerebral Recruitment and Maturation of Dendritic Cells in the Onset and Progression of Experimental Autoimmune Encephalomyelitis," The American Journal of Pathology, Vol. 157, No. 6, 2000, pp. 19912002. doi:10.1016/S0002-9440(10)64838-9

[53] B. Serafini, B. Rosicarelli, R. Magliozzi, E. Stigliano, E. Capello, G. L. Mancardi and F. Aloisi, "Dendritic Cells in Multiple Sclerosis Lesions: Maturation Stage, Myelin Uptake, and Interaction with Proliferating T Cells," Journal of Neuropathology \& Experimental Neurology, Vol. 65, No. 2, 2006, pp. 124-141. doi:10.1097/01.jnen.0000199572.96472.1c

[54] M. A. Friese and L. Fugger, "Pathogenic CD8(+) T Cells in Multiple Sclerosis," Annals of Neurology, Vol. 66, No. 2, 2009, pp. 132-141. doi:10.1002/ana.21744

[55] S. Bourdoulous, E. Beraud, C. Le Page, A. Zamora, A. Ferry, D. Bernard, A. D. Strosberg and P. O. Couraud, "Anergy Induction in Encephalitogenic T Cells by Brain Microvessel Endothelial Cells Is Inhibited by Interleukin-1," European Journal of Immunology, Vol. 25, No. 5, 1995, pp. 1176-1183. doi:10.1002/eji.1830250507

[56] B. O. Fabriek, E. S. Van Haastert, I. Galea, M. M. Polfliet, E. D. Dopp, M. M. Van Den Heuvel, T. K. Van Den Berg, C. J. De Groot, P. Van Der Valk and C. D. Dijkstra, "CD163-Positive Perivascular Macrophages in the $\mathrm{Hu}-$ man CNS Express Molecules for Antigen Recognition and Presentation," Glia, Vol. 51, No. 4, 2005, pp. 297305. doi:10.1002/glia.20208

[57] E. C. Henning, C. A. Ruetzler, M. R. Gaudinski, T. C. Hu, L. L. Latour, J. M. Hallenbeck and S. Warach, "Feridex Preloading Permits Tracking of CNS-Resident Macrophages after Transient Middle Cerebral Artery Occlusion," Journal of Cerebral Blood Flow \& Metabolism, Vol. 29, No. 7, 2009, pp. 1229-1239. doi:10.1038/jcbfm. 2009.48

[58] W. F. Hickey and H. Kimura, "Perivascular Microglial Cells of the CNS Are Bone Marrow-Derived and Present Antigen in Vivo," Science, Vol. 239, No. 4837, 1988, pp. 290-292. doi:10.1126/science. 3276004

[59] M. M. Polfliet, F. van de Veerdonk, E. A. Dopp, E. M. van Kesteren-Hendrikx, N. van Rooijen, C. D. Dijkstra and T. K. van den Berg, "The Role of Perivascular and Meningeal Macrophages in Experimental Allergic Encephalomyelitis," Journal of Neuroimmunology, Vol. 122, No. 1-2, 2002, pp. 1-8. doi:10.1016/S0165-5728(01)00445-3

[60] W. E. Thomas, "Brain Macrophages: On the Role of Pericytes and Perivascular Cells," Brain Research Reviews, Vol. 31, No. 1, 1999, pp. 42-57. doi:10.1016/S0165-0173(99)00024-7

[61] H. Kettenmann, U. K. Hanisch, M. Noda and A. Verkhratsky, "Physiology of Microglia," Physiological Reviews, Vol. 91, No. 2, 2011, pp. 461-553. doi:10.1152/physrev.00011.2010

[62] F. Ginhoux, M. Greter, M. Leboeuf, S. Nandi, P. See, S. Gokhan, M. F. Mehler, S. J. Conway, L. G. Ng, E. R. Stanley, I. M. Samokhvalov and M. Merad, "Fate Mapping Analysis Reveals That Adult Microglia Derive from Primitive Macrophages," Science, Vol. 330, No. 6005, 2010, pp. 841-845. doi:10.1126/science. 1194637

[63] S. H. Orkin and L. I. Zon, "Hematopoiesis: An Evolving Paradigm for Stem Cell Biology," Cell, Vol. 132, No. 4, 2008, pp. 631-644. doi:10.1016/j.cell.2008.01.025

[64] H. Neumann, M. R. Kotter and R. J. Franklin, "Debris Clearance by Microglia: An Essential Link between Degeneration and Regeneration," Brain, Vol. 132, No. 2, 2009, pp. 288-295.

[65] M. B. Graeber, "Changing Face of Microglia," Science, Vol. 330, No. 6005, 2010, pp. 783-788. doi:10.1126/science.1190929

[66] F. Aloisi, "Immune Function of Microglia," Glia, Vol. 36, No. 2, 2001, pp. 165-179. doi:10.1002/glia.1106

[67] K. Saijo and C. K. Glass, "Microglial Cell Origin and Phenotypes in Health and Disease," Nature Reviews Immunology, Vol. 11, No. 11, 2011, pp. 775-787. doi:10.1038/nri3086

[68] F. Aloisi, F. Ria and L. Adorini, "Regulation of T-Cell Responses by CNS Antigen-Presenting Cells: Different Roles for Microglia and Astrocytes," Immunology Today, Vol. 21, No. 3, 2000, pp. 141-147. doi:10.1016/S0167-5699(99)01512-1

[69] M. K. Matyszak, S. Denis-Donini, S. Citterio, R. Longhi, F. Granucci and P. Ricciardi-Castagnoli, "Microglia Induce Myelin Basic Protein-Specific T Cell Anergy or T Cell Activation, According to Their State of Activation," European Journal of Immunology, Vol. 29, No. 10, 1999, pp. 3063-3076.

doi:10.1002/(SICI)1521-4141(199910)29:10<3063::AIDIMMU3063>3.0.CO;2-G

[70] F. Aloisi, F. Ria, S. Columba-Cabezas, H. Hess, G. Penna and L. Adorini, "Relative Efficiency of Microglia, Astrocytes, Dendritic Cells and B Cells in Naive CD4+ T Cell Priming and Th1/Th2 Cell Restimulation," European Journal of Immunology, Vol. 29, No. 9, 1999, pp. 27052714.

doi:10.1002/(SICI)1521-4141(199909)29:09<2705::AIDIMMU2705>3.0.CO;2-1

[71] E. J. McMahon, S. L. Bailey, C. V. Castenada, H. Waldner and S. D. Miller, "Epitope Spreading Initiates in the CNS in Two Mouse Models of Multiple Sclerosis," $\mathrm{Na}$ ture Medicine, Vol. 11, No. 3, 2005, pp. 335-339. doi: $10.1038 / \mathrm{nm} 1202$

[72] [72] C. Beauvillain, S. Donnou, U. Jarry, M. Scotet, H. Gascan, Y. Delneste, P. Guermonprez, P. Jeannin and D. Couez, "Neonatal and Adult Microglia Cross-Present Exogenous Antigens," Glia, Vol. 56, No. 1, 2008, pp. 6977. doi:10.1002/glia.20565

[73] F. Aloisi, F. Ria, G. Penna and L. Adorini, "Microglia Are More Efficient than Astrocytes in Antigen Processing and in Th1 but Not Th2 Cell Activation," The Journal of Immunology, Vol. 160, No. 10, 1998, pp. 4671-4680. 
[74] E. D. Ponomarev, L. P. Shriver, K. Maresz and B. N. Dittel, "Microglial Cell Activation and Proliferation Precedes the Onset of CNS Autoimmunity," Journal of Neuroscience Research, Vol. 81, No. 3, 2005, pp. 374-389. doi:10.1002/jnr.20488

[75] A. C. Murphy, S. J. Lalor, M. A. Lynch and K. H. Mills, "Infiltration of Th1 and Th17 Cells and Activation of Microglia in the CNS during the Course of Experimental Autoimmune Encephalomyelitis," Brain, Behavior, and Immunity, Vol. 24, No. 4, 2010, pp. 641-651. doi:10.1016/j.bbi.2010.01.014

[76] F. L. Heppner, M. Greter, D. Marino, J. Falsig, G. Raivich, N. Hovelmeyer, A. Waisman, T. Rulicke, M. Prinz, J. Priller, B. Becher and A. Aguzzi, "Experimental Autoimmune Encephalomyelitis Repressed by Microglial Paralysis," Nature Medicine, Vol. 11, No. 2, 2005, pp. 146-152. doi:10.1038/nm1177

[77] A. L. Ford, E. Foulcher, F. A. Lemckert and J. D. Sedgwick, "Microglia Induce CD4 T Lymphocyte Final Effector Function and Death," The Journal of Experimental Medicine, Vol. 184, No. 5, 1996, pp. 1737-1745. doi:10.1084/jem.184.5.1737

[78] F. Geissmann, M. G. Manz, S. Jung, M. H. Sieweke, M. Merad and K. Ley, "Development of Monocytes, Macrophages, and Dendritic Cells," Science, Vol. 327, No. 5966, 2010, pp. 656-661. doi:10.1126/science.1178331

[79] E. D. Ponomarev, K. Maresz, Y. Tan and B. N. Dittel, "CNS-Derived Interleukin-4 Is Essential for the Regulation of Autoimmune Inflammation and Induces a State of Alternative Activation in Microglial Cells," The Journal of Neuroscience, Vol. 27, No. 40, 2007, pp. 10714-10721. doi:10.1523/JNEUROSCI.1922-07.2007

[80] K. A. Kigerl, J. C. Gensel, D. P. Ankeny, J. K. Alexander, D. J. Donnelly and P. G. Popovich, "Identification of Two Distinct Macrophage Subsets with Divergent Effects Causing Either Neurotoxicity or Regeneration in the Injured Mouse Spinal Cord," The Journal of Neuroscience, Vol. 29, No. 43, 2009, pp. 13435-13444. doi:10.1523/JNEUROSCI.3257-09.2009

[81] Z. Zhang, Z. Y. Zhang, J. Schittenhelm, Y. Wu, R. Meyermann and H. J. Schluesener, "Parenchymal Accumulation of CD163+ Macrophages/Microglia in Multiple Sclerosis Brains," Journal of Neuroimmunology, Vol. 237, No. 1-2, 2011, pp. 73-79. doi:10.1016/j.jneuroim.2011.06.006

[82] B. Ajami, J. L. Bennett, C. Krieger, K. M. McNagny and F. M. Rossi, "Infiltrating Monocytes Trigger EAE Progression, but Do Not Contribute to the Resident Microglia Pool," Nature Neuroscience, Vol. 14, No. 9, 2011, pp. 1142-1149. doi:10.1038/nn.2887

[83] B. Almolda, B. Gonzalez and B. Castellano, "Activated Microglial Cells Acquire an Immature Dendritic Cell Phenotype and May Terminate the Immune Response in an Acute Model of EAE," Journal of Neuroimmunology, Vol. 223, No. 1-2, 2010, pp. 39-54. doi:10.1016/j.jneuroim.2010.03.021

[84] K. D. McCoy and G. Le Gros, "The Role of CTLA-4 in the Regulation of T Cell Immune Responses," Immunology \& Cell Biology, Vol. 77, No. 1, 1999, pp. 1-10. doi:10.1046/j.1440-1711.1999.00795.x
[85] N. J. Allen and B. A. Barres, "Neuroscience: Glia More than Just Brain Glue," Nature, Vol. 457, No. 7230, 2009, pp. 675-677. doi:10.1038/457675a

[86] G. C. Petzold and V. N. Murthy, "Role of Astrocytes in Neurovascular Coupling," Neuron, Vol. 71, No. 5, 2011, pp. 782-797. doi:10.1016/j.neuron.2011.08.009

[87] P. A. Carpentier, W. S. Begolka, J. K. Olson, A. Elhofy, W. J. Karpus and S. D. Miller, "Differential Activation of Astrocytes by Innate and Adaptive Immune Stimuli," Glia, Vol. 49, No. 3, 2005, pp. 360-374. doi:10.1002/glia.20117

[88] A. Fontana, W. Fierz and H. Wekerle, "Astrocytes Present Myelin Basic Protein to Encephalitogenic T-Cell lines," Nature, Vol. 307, No. 5948, 1984, pp. 273-276. doi: $10.1038 / 307273 \mathrm{a} 0$

[89] J. M. Soos, J. Morrow, T. A. Ashley, B. E. Szente, E. K. Bikoff and S. S. Zamvil, "Astrocytes Express Elements of the Class II Endocytic Pathway and Process Central Nervous System Autoantigen for Presentation to Encephalitogenic T Cells," The Journal of Immunology, Vol. 161, No. 11, 1998, pp. 5959-5966.

[90] O. Stuve, S. Youssef, A. J. Slavin, C. L. King, J. C. Patarroyo, D. L. Hirschberg, W. J. Brickey, J. M. Soos, J. F. Piskurich, H. A. Chapman and S. S. Zamvil, "The Role of the MHC Class II Transactivator in Class II Expression and Antigen Presentation by Astrocytes and in Susceptibility to Central Nervous System Autoimmune Disease," The Journal of Immunology, Vol. 169, No. 12, 2002, pp. 6720-6732.

[91] A. Cornet, E. Bettelli, M. Oukka, C. Cambouris, V. Avellana-Adalid, K. Kosmatopoulos and R. S. Liblau, "Role of Astrocytes in Antigen Presentation and Naive T-Cell Activation," Journal of Neuroimmunology, Vol. 106, No. 1-2, 2000, pp. 69-77. doi:10.1016/S0165-5728(99)00215-5

[92] K. Baur, M. Rauer, K. Richter, A. Pagenstecher, J. Gotz, J. Hausmann and P. Staeheli, "Antiviral CD8 T Cells Recognize Borna Disease Virus Antigen Transgenically Expressed in Either Neurons or Astrocytes," Journal of Virology, Vol. 82, No. 6, 2008, pp. 3099-3108. doi:10.1128/JVI.02479-07

[93] K. Williams, E. Ulvestad, A. Waage, J. P. Antel and J. McLaurin, "Activation of Adult Human Derived Microglia by Myelin Phagocytosis in Vitro," Journal of Neuroscience Research, Vol. 38, No. 4, 1994, pp. 433-443. doi:10.1002/jnr.490380409

[94] R. M. Ransohoff and M. A. Brown, "Innate Immunity in the Central Nervous System," The Journal of Clinical Investigation, Vol. 122, No. 4, 2012, pp. 1164-1171. doi:10.1172/JCI58644

[95] D. N. Hart and J. W. Fabre, "Demonstration and Characterization of Ia-Positive Dendritic Cells in the Interstitial Connective Tissues of Rat Heart and Other Tissues, but Not Brain," The Journal of Experimental Medicine, Vol. 154, No. 2, 1981, pp. 347-361. doi:10.1084/jem.154.2.347

[96] R. M. Steinman and Z. A. Cohn, "Identification of a Novel Cell Type in Peripheral Lymphoid Organs of Mice. I. Morphology, Quantitation, Tissue Distribution," The 
Journal of Experimental Medicine, Vol. 137, No. 5, 1973, pp. 1142-1162. doi:10.1084/jem.137.5.1142

[97] P. G. McMenamin, R. J. Wealthall, M. Deverall, S. J. Cooper and B. Griffin, "Macrophages and Dendritic Cells in the Rat Meninges and Choroid Plexus: Three-Dimensional Localisation by Environmental Scanning Electron Microscopy and Confocal Microscopy," Cell and Tissue Research, Vol. 313, No. 3, 2003, pp. 259-269. doi:10.1007/s00441-003-0779-0

[98] M. Pashenkov, Y. M. Huang, V. Kostulas, M. Haglund, M. Soderstrom and H. Link, "Two Subsets of Dendritic Cells Are Present in Human Cerebrospinal Fluid," Brain, Vol. 124, No. 3, 2001, pp. 480-492.

[99] M. Greter, F. L. Heppner, M. P. Lemos, B. M. Odermatt, N. Goebels, T. Laufer, R. J. Noelle and B. Becher, "Dendritic Cells Permit Immune Invasion of the CNS in an Animal Model of Multiple Sclerosis," Nature Medicine, Vol. 11, No. 3, 2005, pp. 328-334. doi:10.1038/nm1197

[100] J. Karman, H. H. Chu, D. O. Co, C. M. Seroogy, M. Sandor and Z. Fabry, "Dendritic Cells Amplify T CellMediated Immune Responses in the Central Nervous System," The Journal of Immunology, Vol. 177, No. 11, 2006, pp. 7750-7760.

[101] J. M. Goverman, "Immune Tolerance in Multiple Sclerosis," Immunological Reviews, Vol. 241, No. 1, 2011, pp. 228-240. doi:10.1111/j.1600-065X.2011.01016.x

[102] J. M. Ilarregui and G. A. Rabinovich, "Tolerogenic Dendritic Cells in the Control of Autoimmune Neuroinflammation: An Emerging Role of Protein-Glycan Interactions," Neuroimmunomodulation, Vol. 17, No. 3, 2010, pp. 157-160. doi:10.1159/000258712

[103] M. Ioannou, T. Alissafi, I. Lazaridis, G. Deraos, J. Matsoukas, A. Gravanis, V. Mastorodemos, A. Plaitakis, A. Sharpe, D. Boumpas and P. Verginis, "Crucial Role of Granulocytic Myeloid-Derived Suppressor Cells in the Regulation of Central Nervous System Autoimmune Disease," The Journal of Immunology, Vol. 188, No. 3, 2012, pp. 1136-1146. doi:10.4049/jimmunol.1101816

[104] L. Walter and M. L. Albert, "Cutting Edge: Cross-Presented Intracranial Antigen Primes CD8+ T cells," The Journal of Immunology, Vol. 178, No. 10, 2007, pp. 6038-6042.

[105] L. Santambrogio, S. L. Belyanskaya, F. R. Fischer, B. Cipriani, C. F. Brosnan, P. Ricciardi-Castagnoli, L. J. Stern, J. L. Strominger and R. Riese, "Developmental Plasticity of CNS Microglia," Proceedings of the $\mathrm{Na}$ tional Academy of Sciences of the United States of America, Vol. 98, No. 11, 2001, pp. 6295-6300. doi:10.1073/pnas.111152498

[106] S. Jung, D. Unutmaz, P. Wong, G. Sano, K. De los Santos, T. Sparwasser, S. Wu, S. Vuthoori, K. Ko, F. Zavala, E. G. Pamer, D. R. Littman and R. A. Lang, "In Vivo Depletion of CD11c+ Dendritic Cells Abrogates Priming of CD8+ T Cells by Exogenous Cell-Associated Antigens," Immunity, Vol. 17, No. 2, 2002, pp. 211-220. doi:10.1016/S1074-7613(02)00365-5

[107] R. L. Lindquist, G. Shakhar, D. Dudziak, H. Wardemann, T. Eisenreich, M. L. Dustin and M. C. Nussenzweig, "Visualizing Dendritic Cell Networks in Vivo," Nature
Immunology, Vol. 5, No. 12, 2004, pp. 1243-1250. doi:10.1038/ni1139

[108] K. Bulloch, M. M. Miller, J. Gal-Toth, T. A. Milner, A. Gottfried-Blackmore, E. M. Waters, U. W. Kaunzner, K. Liu, R. Lindquist, M. C. Nussenzweig, R. M. Steinman and B. S. McEwen, "CD11c/EYFP Transgene Illuminates a Discrete Network of Dendritic Cells within the Embryonic, Neonatal, Adult, and Injured Mouse Brain," The Journal of Comparative Neurology, Vol. 508, No. 5, 2008, pp. 687-710. doi:10.1002/cne.21668

[109] C. Prodinger, J. Bunse, M. Kruger, F. Schiefenhovel, C. Brandt, J. D. Laman, M. Greter, K. Immig, F. Heppner, B. Becher and I. Bechmann, "CD11c-Expressing Cells Reside in the Juxtavascular Parenchyma and Extend Processes into the Glia Limitans of the Mouse Nervous System," Acta Neuropathologica, Vol. 121, No. 4, 2011, pp. 445-458. doi:10.1007/s00401-010-0774-y

[110] A. Gottfried-Blackmore, U. W. Kaunzner, J. Idoyaga, J. C. Felger, B. S. McEwen and K. Bulloch, "Acute in Vivo Exposure to Interferon-Gamma Enables Resident Brain Dendritic Cells to Become Effective Antigen Presenting Cells," Proceedings of the National Academy of Sciences of the United States of America, Vol. 106, No. 49, 2009, pp. 20918-20923. doi:10.1073/pnas.0911509106

[111] F. Geissmann, S. Gordon, D. A. Hume, A. M. Mowat and G. J. Randolph, "Unravelling Mononuclear Phagocyte Heterogeneity," Nature Reviews Immunology, Vol. 10, No. 6, 2010, pp. 453-460. doi:10.1038/nri2784

[112] S. L. Bailey, B. Schreiner, E. J. McMahon and S. D. Miller, "CNS Myeloid DCs Presenting Endogenous Myelin Peptides 'Preferentially' Polarize CD4+ T(H)-17 Cells in Relapsing EAE," Nature Immunology, Vol. 8, No. 2, 2007, pp. 172-180. doi:10.1038/ni1430

[113] T. Olsson, "Multiple Sclerosis:Cerebrospinal Fluid," Annals of Neurology, Vol. 36, 1994, pp. S100-S102. doi:10.1002/ana.410360723

[114] T. L. Sorensen, M. Tani, J. Jensen, V. Pierce, C. Lucchinetti, V. A. Folcik, S. Qin, J. Rottman, F. Sellebjerg, R. M. Strieter, J. L. Frederiksen and R. M. Ransohoff, "Expression of Specific Chemokines and Chemokine Receptors in the Central Nervous System of Multiple Sclerosis Patients," The Journal of Clinical Investigation, Vol. 103, No. 6, 1999, pp. 807-815. doi:10.1172/JCI5150

[115] H. L. Weiner, "Multiple Sclerosis Is an Inflammatory TCell-Mediated Autoimmune Disease," Archives of Neurology, Vol. 61, No. 10, 2004, pp. 1613-1615. doi:10.1001/archneur.61.10.1613

[116] C. Lucchinetti, W. Bruck, J. Parisi, B. Scheithauer, M. Rodriguez and H. Lassmann, "Heterogeneity of Multiple Sclerosis Lesions: Implications for the Pathogenesis of Demyelination," Annals of Neurology, Vol. 47, No. 6, 2000, pp. 707-717.

doi:10.1002/1531-8249(200006)47:6<707::AID-ANA3 $>3$ .0.CO;2-Q

[117] J. K. Olson, T. N. Eagar and S. D. Miller, "Functional Activation of Myelin-Specific T Cells by Virus-Induced Molecular Mimicry," The Journal of Immunology, Vol. 169, No. 5, 2002, pp. 2719-2726.

[118] J. D. Kriesel, M. R. Hobbs, B. B. Jones, B. Milash, R. M. 
Nagra and K. F. Fischer, "Deep Sequencing for the Detection of Virus-Like Sequences in the Brains of Patients with Multiple Sclerosis: Detection of GBV-C in Human Brain," PLoS One, Vol. 7, No. 3, 2012, Article ID: e31886. doi:10.1371/journal.pone.0031886

[119] M. H. Barnett and J. W. Prineas, "Relapsing and Remitting Multiple Sclerosis: Pathology of the Newly Forming Lesion," Annals of Neurology, Vol. 55, No. 4, 2004, pp. 458-468. doi:10.1002/ana.20016

[120] M. H. Barnett and I. Sutton, "The Pathology of Multiple Sclerosis: A Paradigm Shift," Current Opinion in Neurology, Vol. 19, No. 3, 2006, pp. 242-247. doi:10.1097/01.wco.0000227032.47458.cb

[121] G. Locatelli, S. Wortge, T. Buch, B. Ingold, F. Frommer, B. Sobottka, M. Kruger, K. Karram, C. Buhlmann, I. Bechmann, F. L. Heppner, A. Waisman and B. Becher, "Primary Oligodendrocyte Death Does Not Elicit AntiCNS Immunity," Nature Neuroscience, Vol. 15, No. 4, 2012, pp. 543-550. doi:10.1038/nn.3062

[122] H. B. Pohl, C. Porcheri, T. Mueggler, L. C. Bachmann, G. Martino, D. Riethmacher, R. J. Franklin, M. Rudin and U. Suter, "Genetically Induced Adult Oligodendrocyte Cell Death Is Associated with Poor Myelin Clearance, Reduced Remyelination, and Axonal Damage," The Journal of Neuroscience, Vol. 31, No. 3, 2011, pp. 1069-1080. doi:10.1523/JNEUROSCI.5035-10.2011

[123] T. Henics and D. N. Wheatley, "Cytoplasmic Vacuolation, Adaptation and Cell Death: A View on New Perspectives and Features," Biology of the Cell, Vol. 91, No. 7, 1999, pp. 485-498. doi:10.1016/S0248-4900(00)88205-2

[124] C. M. Poser, "The Role of Trauma in the Pathogenesis of Multiple Sclerosis: A Review," Clinical Neurology and Neurosurgery, Vol. 96, No. 2, 1994, pp. 103-110. doi:10.1016/0303-8467(94)90042-6

[125] A. G. Kermode, A. J. Thompson, P. Tofts, D. G. MacManus, B. E. Kendall, D. P. Kingsley, I. F. Moseley, P. Rudge and W. I. McDonald, "Breakdown of the Blood-Brain Barrier Precedes Symptoms and Other MRI Signs of New Lesions in Multiple Sclerosis. Pathogenetic and Clinical Implications," Brain, Vol. 113, No. 5, 1990, pp. 1477-1489. doi:10.1093/brain/113.5.1477

[126] S. Hisahara, T. Araki, F. Sugiyama, K. Yagami, M. Suzuki, K. Abe, K. Yamamura, J. Miyazaki, T. Momoi, T. Saruta, C. C. Bernard, H. Okano and M. Miura, "Targeted Expression of Baculovirus p35 Caspase Inhibitor in Oligodendrocytes Protects Mice against Autoimmune-Mediated Demyelination," The EMBO Journal, Vol. 19, No. 3, 2000, pp. 341-348. doi:10.1093/emboj/19.3.341

[127] M. L. Albert, S. F. Pearce, L. M. Francisco, B. Sauter, P. Roy, R. L. Silverstein and N. Bhardwaj, "Immature Dendritic Cells Phagocytose Apoptotic Cells via Alphavbeta5 and CD36, and Cross-Present Antigens to Cytotoxic T Lymphocytes," The Journal of Experimental Medicine, Vol. 188, No. 7, 1998, pp. 1359-1368. doi:10.1084/jem.188.7.1359

[128] M. L. Albert, B. Sauter and N. Bhardwaj, "Dendritic Cells Acquire Antigen from Apoptotic Cells and Induce Class I-Restricted CTLs," Nature, Vol. 392, No. 6671, 1998, pp. 86-89. doi:10.1038/32183
[129] N. E. Blachere, R. B. Darnell and M. L. Albert, "Apoptotic Cells Deliver Processed Antigen to Dendritic Cells for Cross-Presentation," PLoS Biology, Vol. 3, No. 6, 2005, p. e185. doi:10.1371/journal.pbio.0030185

[130] F. Meloni, D. Accapezzato, C. Agresti, F. Aloisi, G. Ristori, M. Salvetti, R. Furlan, G. Martino, V. Barnaba and M. Paroli, "Dendritic Cells Loaded with Apoptotic Oligodendrocytes as a Source of Myelin T-Cell Epitopes in Multiple Sclerosis," Clinical Immunology, Vol. 129, No. 2, 2008, pp. 286-294. doi:10.1016/j.clim.2008.07.017

[131]H. Kono and K. L. Rock, "How Dying Cells Alert the Immune System to Danger," Nature Reviews Immunology, Vol. 8, No. 4, 2008, pp. 279-289. doi:10.1038/nri2215

[132] M. P. Mycko, H. Cwiklinska, J. Szymanski, B. Szymanska, G. Kudla, L. Kilianek, A. Odyniec, C. F. Brosnan and K. W. Selmaj, "Inducible Heat Shock Protein 70 Promotes Myelin Autoantigen Presentation by the HLA Class II," The Journal of Immunology, Vol. 172, No. 1, 2004, pp. 202-213.

[133] B. Ravishankar, H. Liu, R. Shinde, P. Chandler, B. Baban, M. Tanaka, D. H. Munn, A. L. Mellor, M. C. Karlsson and T. L. McGaha, "Tolerance to Apoptotic Cells Is Regulated by Indoleamine 2,3-Dioxygenase," Proceedings of the National Academy of Sciences of the United States of America, Vol. 109, No. 10, 2012, pp. 3909-3914. doi:10.1073/pnas.1117736109

[134] Y. Wang, M. A. Lawson, K. W. Kelley and R. Dantzer, "Primary Murine Microglia Are Resistant to Nitric Oxide Inhibition of Indoleamine 2,3-Dioxygenase," Brain, Behavior, and Immunity, Vol. 24, No. 8, 2010, pp. 12491253. doi:10.1016/j.bbi.2010.04.015

[135] A. Andersson, R. Covacu, D. Sunnemark, A. I. Danilov, A. Dal Bianco, M. Khademi, E. Wallstrom, A. Lobell, L. Brundin, H. Lassmann and R. A. Harris, "Pivotal Advance: HMGB1 Expression in Active Lesions of Human and Experimental Multiple Sclerosis," Journal of Leukocyte Biology, Vol. 84, No. 5, 2008, pp. 1248-1255. doi: $10.1189 / \mathrm{jlb} .1207844$

[136] R. A. Williamson, M. P. Burgoon, G. P. Owens, O. Ghausi, E. Leclerc, L. Firme, S. Carlson, J. Corboy, P. W. Parren, P. P. Sanna, D. H. Gilden and D. R. Burton, "Anti-DNA Antibodies Are a Major Component of the Intrathecal B Cell Response in Multiple Sclerosis," Proceedings of the National Academy of Sciences of the United States of America, Vol. 98, No. 4, 2001, pp. 17931798. doi:10.1073/pnas.031567598

[137] L. K. Peterson, T. Masaki, S. R. Wheelwright, I. Tsunoda and R. S. Fujinami, "Cross-Reactive Myelin Antibody Induces Renal Pathology," Autoimmunity, Vol. 41, No. 7, 2008, pp. 526-536. doi:10.1080/08916930802128680

[138] L. K. Peterson, I. Tsunoda, T. Masaki and R. S. Fujinami, "Polyreactive Myelin Oligodendrocyte Glycoprotein Antibodies: Implications for Systemic Autoimmunity in Progressive Experimental Autoimmune Encephalomyelitis," Journal of Neuroimmunology, Vol. 183, No. 1-2, 2007, pp. 69-80. doi:10.1016/j.jneuroim.2006.11.024

[139] M. Cieslak, F. Kukulski and M. Komoszynski, "Emerging Role of Extracellular Nucleotides and Adenosine in Multiple Sclerosis," Purinergic Signalling, Vol. 7, No. 4, 
2011, pp. 393-402. doi:10.1007/s11302-011-9250-y

[140] G. Birnbaum, L. Kotilinek, P. Schlievert, H. B. Clark, J. Trotter, E. Horvath, E. Gao, M. Cox and P. E. Braun, "Heat Shock Proteins and Experimental Autoimmune Encephalomyelitis (EAE): I. Immunization with a Peptide of the Myelin Protein 2',3' Cyclic Nucleotide 3' Phosphodiesterase That Is Cross-Reactive with a Heat Shock Protein Alters the Course of EAE," Journal of Neuroscience Research, Vol. 44, No. 4, 1996, pp. 381-396. doi:10.1002/(SICI)1097-4547(19960515)44:4<381::AID$\underline{\mathrm{JNR} 10>3.0 . \mathrm{CO} ; 2-5}$

[141] M. Rickmann and J. R. Wolff, "S100 Immunoreactivity in a Subpopulation of Oligodendrocytes and Ranvier'S Nodes of Adult Rat Brain," Neuroscience Letters, Vol. 186, No. 1, 1995, pp. 13-16. doi:10.1016/0304-3940(95)11269-3

[142] R. A. Sobel and M. E. Mitchell, "Fibronectin in Multiple Sclerosis Lesions," The American Journal of Pathology, Vol. 135, No. 1, 1989, pp. 161-168.

[143] R. A. Sobel, E. E. Schneeberger and R. B. Colvin, "The Immunopathology of Acute Experimental Allergic Encephalomyelitis. V. A Light Microscopic and Ultrastructural Immunohistochemical Analysis of Fibronectin and Fibrinogen," The American Journal of Pathology, Vol. 131, No. 3, 1988, pp. 547-558.

[144] P. Y. Paterson, C. S. Koh and H. C. Kwaan, "Role of the Clotting System in the Pathogenesis of Neuroimmunologic Disease," Federation Proceedings, Vol. 46, No. 1, 1987, pp. 91-96.

[145] Z. Siskova, W. Baron, H. de Vries and D. Hoekstra, "Fibronectin Impedes 'Myelin' Sheet-Directed Flow in Oligodendrocytes: A Role for a Beta 1 Integrin-Mediated PKC Signaling Pathway in Vesicular Trafficking," Molecular and Cellular Neuroscience, Vol. 33, No. 2, 2006, pp. 150-159. doi:10.1016/j.mcn.2006.07.001

[146] S. A. Back, T. M. Tuohy, H. Chen, N. Wallingford, A. Craig, J. Struve, N. L. Luo, F. Banine, Y. Liu, A. Chang, B. D. Trapp, B. F. Bebo, Jr., M. S. Rao and L. S. Sherman, "Hyaluronan Accumulates in Demyelinated Lesions and Inhibits Oligodendrocyte Progenitor Maturation," Nature Medicine, Vol. 11, No. 9, 2005, pp. 966-972.

[147] Z. Fabry, H. A. Schreiber, M. G. Harris and M. Sandor, "Sensing the Microenvironment of the Central Nervous System: Immune Cells in the Central Nervous System and Their Pharmacological Manipulation," Current Opinion in Pharmacology, Vol. 8, No. 4, 2008, pp. 496-507. doi:10.1016/i.coph.2008.07.009

[148] J. A. Sloane, C. Batt, Y. Ma, Z. M. Harris, B. Trapp and T. Vartanian, "Hyaluronan Blocks Oligodendrocyte Progenitor Maturation and Remyelination through TLR2," Proceedings of the National Academy of Sciences of the United States of America, Vol. 107, No. 25, 2010, pp. 11555-11560. doi:10.1073/pnas.1006496107

[149] A. M. de Mestre, M. A. Staykova, J. R. Hornby, D. O. Willenborg and M. D. Hulett, "Expression of the Heparan Sulfate-Degrading Enzyme Heparanase Is Induced in Infiltrating CD4+ T Cells in Experimental Autoimmune Encephalomyelitis and Regulated at the Level of Transcription by Early Growth Response Gene 1," Journal of
Leukocyte Biology, Vol. 82, No. 5, 2007, pp. 1289-1300. doi: $10.1189 / \mathrm{jlb} .0507315$

[150] J. van Horssen, L. Bo, C. M. Vos, I. Virtanen and H. E. de Vries, "Basement Membrane Proteins in Multiple Sclerosis-Associated Inflammatory Cuffs: Potential Role in Influx and Transport of Leukocytes," Journal of Neuropathology \& Experimental Neurology, Vol. 64, No. 8, 2005, pp. 722-729. doi:10.1097/01.jnen.0000173894.09553.13

[151] S. Miyake, T. Sakurai, K. Okumura and H. Yagita, "Identification of Collagen and Laminin Receptor Integrins on Murine T Lymphocytes," European Journal of Immunology, Vol. 24, No. 9, 1994, pp. 2000-2005. doi:10.1002/eji.1830240910

[152] J. T. Maikos, R. A. Elias and D. I. Shreiber, "Mechanical Properties of Dura Mater from the Rat Brain and Spinal Cord," Journal of Neurotrauma, Vol. 25, No. 1, 2008, pp. 38-51. doi:10.1089/neu.2007.0348

[153] S. Chandler, J. Cossins, J. Lury and G. Wells, "Macrophage Metalloelastase Degrades Matrix and Myelin Proteins and Processes a Tumour Necrosis Factor-Alpha Fusion Protein," Biochemical and Biophysical Research Communications, Vol. 228, No. 2, 1996, pp. 421-429. doi:10.1006/bbrc.1996.1677

[154] R. Debret, F. Antonicelli, A. Theill, W. Hornebeck, P. Bernard, M. Guenounou and R. Le Naour, "Elastin-Derived Peptides Induce a T-Helper Type 1 Polarization of Human Blood Lymphocytes," Arteriosclerosis, Thrombosis, and Vascular Biology, Vol. 25, No. 7, 2005, pp. 1353-1358. doi:10.1161/01.ATV.0000168412.50855.9f

[155] M. Stancic, J. van Horssen, V. L. Thijssen, H. J. Gabius, P. van der Valk, D. Hoekstra and W. Baron, "Increased Expression of Distinct Galectins in Multiple Sclerosis Lesions," Neuropathology and Applied Neurobiology, Vol. 37, No. 6, 2011, pp. 654-671. doi:10.1111/j.1365-2990.2011.01184.x

[156] J. M. Ilarregui, D. O. Croci, G. A. Bianco, M. A. Toscano, M. Salatino, M. E. Vermeulen, J. R. Geffner and G. A. Rabinovich, "Tolerogenic Signals Delivered by Dendritic Cells to $\mathrm{T}$ Cells through a Galectin-1-Driven Immunoregulatory Circuit Involving Interleukin 27 and Interleukin 10," Nature Immunology, Vol. 10, No. 9, 2009, pp. 981-991. doi:10.1038/ni.1772

[157] J. Wang, Z. H. Lu, H. J. Gabius, C. Rohowsky-Kochan, R. W. Ledeen and G. Wu, "Cross-Linking of GM1 Ganglioside by Galectin-1 Mediates Regulatory T Cell Activity Involving TRPC5 Channel Activation: Possible Role in Suppressing Experimental Autoimmune Encephalomyelitis," The Journal of Immunology, Vol. 182, No. 7, 2009, pp. 4036-4045. doi:10.4049/jimmunol.0802981

[158] A. Grigorian and M. Demetriou, "Mgat5 Deficiency in T Cells and Experimental Autoimmune Encephalomyelitis," ISRN Neurology, Vol. 2011, 2011, Article ID: 374314. doi: $10.5402 / 2011 / 374314$

[159] M. Demetriou, M. Granovsky, S. Quaggin and J. W. Dennis, "Negative Regulation of T-Cell Activation and Autoimmunity by Mgat5 N-Glycosylation," Nature, Vol. 409, No. 6821, 2001, pp. 733-739. doi: $10.1038 / 35055582$ 
[160] S. U. Lee, A. Grigorian, J. Pawling, I. J. Chen, G. Gao, T. Mozaffar, C. McKerlie and M. Demetriou, "N-Glycan Processing Deficiency Promotes Spontaneous Inflammatory Demyelination and Neurodegeneration," The Journal of Biological Chemistry, Vol. 282, No. 46, 2007, pp. 33725-33734. doi:10.1074/jbc.M704839200

[161] K. Liu and M. C. Nussenzweig, "Origin and Development of Dendritic Cells," Immunological Reviews, Vol. 234, No. 1, 2010, pp. 45-54. doi:10.1111/j.0105-2896.2009.00879.x

[162] M. Colonna, G. Trinchieri and Y. J. Liu, "Plasmacytoid Dendritic Cells in Immunity," Nature Immunology, Vol. 5, No. 12, 2004, pp. 1219-1226. doi:10.1038/ni1141

[163] B. D. Clarkson, E. Heninger, M. G. Harris, J. Lee, M. Sandor and Z. Fabry, "Innate-Adaptive Crosstalk: How Dendritic Cells Shape Immune Responses in the CNS," Advances in Experimental Medicine and Biology, Vol. 946, 2012, pp. 309-333. doi:10.1007/978-1-4614-0106-3 18

[164] D. Dissanayake, H. Hall, N. Berg-Brown, A. R. Elford, S. R. Hamilton, K. Murakami, L. S. Deluca, J. L. Gommerman and P. S. Ohashi, "Nuclear Factor-Kappab1 Controls the Functional Maturation of Dendritic Cells and Prevents the Activation of Autoreactive T Cells," Nature Medicine, Vol. 17, No. 12, 2011, pp. 1663-1667. doi: $10.1038 / \mathrm{nm} .2556$

[165] A. L. Zozulya, S. Ortler, J. Lee, C. Weidenfeller, M. Sandor, H. Wiendl and Z. Fabry, "Intracerebral Dendritic Cells Critically Modulate Encephalitogenic versus Regulatory Immune Responses in the CNS," The Journal of Neuroscience, Vol. 29, No. 1, 2009, pp. 140-152. doi:10.1523/JNEUROSCI.2199-08.2009

[166] P. Deshpande, I. L. King and B. M. Segal, "Cutting Edge: CNS CD11c+ Cells from Mice with Encephalomyelitis Polarize Th17 Cells and Support CD25+ CD4+ T CellMediated Immunosuppression, Suggesting Dual Roles in the Disease Process," The Journal of Immunology, Vol. 178, No. 11, 2007, pp. 6695-6699.

[167] M. N. Alonso, M. T. Wong, A. L. Zhang, D. Winer, M. M. Suhoski, L. L. Tolentino, J. Gaitan, M. G. Davidson, T. H. Kung, D. M. Galel, K. C. Nadeau, J. Kim, P. J. Utz, K. Soderstrom and E. G. Engleman, "T(H)1, T(H)2, and $\mathrm{T}(\mathrm{H}) 17$ Cells Instruct Monocytes to Differentiate into Specialized Dendritic Cell Subsets," Blood, Vol. 118, No. 12, 2011, pp. 3311-3320. doi:10.1182/blood-2011-03-341065

[168] M. El-Behi, B. Ciric, H. Dai, Y. Yan, M. Cullimore, F. Safavi, G. X. Zhang, B. N. Dittel and A. Rostami, "The Encephalitogenicity of $\mathrm{T}(\mathrm{H}) 17$ Cells Is Dependent on IL-1- and IL-23-Induced Production of the Cytokine GM-CSF," Nature Immunology, Vol. 12, No. 6, 2011, pp. 568-575. doi:10.1038/ni.2031

[169] K. Poppensieker, D. M. Otte, B. Schurmann, A. Limmer, P. Dresing, E. Drews, B. Schumak, L. Klotz, J. Raasch, A. Mildner, A. Waisman, S. Scheu, P. Knolle, I. Forster, M.
Prinz, W. Maier, A. Zimmer and J. Alferink, "CC Chemokine Receptor 4 Is Required for Experimental Autoimmune Encephalomyelitis by Regulating GM-CSF and IL-23 Production in Dendritic Cells," Proceedings of the National Academy of Sciences of the United States of America, Vol. 109, No. 10, 2012, pp. 3897-3902. doi:10.1073/pnas.1114153109

[170] R. A. Maldonado and U. H. von Andrian, "How Tolerogenic Dendritic Cells Induce Regulatory T Cells," Advances in Immunology, Vol. 108, 2010, pp. 111-165. doi:10.1016/B978-0-12-380995-7.00004-5

[171] S. M. Opal and V. A. DePalo, “Anti-Inflammatory Cytokines," Chest, Vol. 117, No. 4, 2000, pp. 1162-1172. doi:10.1378/chest.117.4.1162

[172] Y. Laouar, T. Town, D. Jeng, E. Tran, Y. Wan, V. K. Kuchroo and R. A. Flavell, "TGF-Beta Signaling in Dendritic Cells Is a Prerequisite for the Control of Autoimmune Encephalomyelitis," Proceedings of the National Academy of Sciences of the United States of America, Vol. 105, No. 31, 2008, pp. 10865-10870. doi: $10.1073 /$ pnas.0805058105

[173] M. Delgado, E. Gonzalez-Rey and D. Ganea, "The Neuropeptide Vasoactive Intestinal Peptide Generates Tolerogenic Dendritic Cells," The Journal of Immunology, Vol. 175, No. 11, 2005, pp. 7311-7324.

[174] M. G. Toscano, M. Delgado, W. Kong, F. Martin, M. Skarica and D. Ganea, "Dendritic Cells Transduced with Lentiviral Vectors Expressing VIP Differentiate into VIP-Secreting Tolerogenic-Like DCs," Molecular Therapy, Vol. 18, No. 5, 2010, pp. 1035-1045. doi:10.1038/mt.2009.293

[175] S. L. Bailey, P. A. Carpentier, E. J. McMahon, W. S. Begolka and S. D. Miller, "Innate and Adaptive Immune Responses of the Central Nervous System," Critical Reviews in Immunology, Vol. 26, No. 2, 2006, pp. 149-188.

[176] S. L. Bailey-Bucktrout, S. C. Caulkins, G. Goings, J. A. Fischer, A. Dzionek and S. D. Miller, "Cutting Edge: Central Nervous System Plasmacytoid Dendritic Cells Regulate the Severity of Relapsing Experimental Autoimmune Encephalomyelitis," The Journal of Immunology, Vol. 180, No. 10, 2008, pp. 6457-6461.

[177] M. Irla, N. Kupfer, T. Suter, R. Lissilaa, M. Benkhoucha, J. Skupsky, P. H. Lalive, A. Fontana, W. Reith and S. Hugues, "MHC Class II-Restricted Antigen Presentation by Plasmacytoid Dendritic Cells Inhibits T Cell-Mediated Autoimmunity," The Journal of Experimental Medicine, Vol. 207, No. 9, 2010, pp. 1891-1905. doi:10.1084/jem.20092627

[178] Y. Yan, G. X. Zhang, B. Gran, F. Fallarino, S. Yu, H. Li, M. L. Cullimore, A. Rostami and H. Xu, "IDO Upregulates Regulatory T Cells via Tryptophan Catabolite and Suppresses Encephalitogenic T Cell Responses in Experimental Autoimmune Encephalomyelitis," The Journal of Immunology, Vol. 185, No. 10, 2010, pp. 5953-5961. doi:10.4049/jimmunol.1001628 